\title{
Studies on the Quality and Vulnerability of Groundwater to Contamination
}

\author{
Izinyon, O.C Meindinyo, L.I Ilaboya, I.R \\ Department of Civil Engineering, Faculty of Engineering, PMB 1154, University of Benin, Benin City, Edo \\ State. Nigeria
}

\begin{abstract}
To effectively and properly protect groundwater, it is crucial being able to identify areas where groundwater may be most vulnerable to contamination and translate this information into vulnerability maps that can be used by potential end-users, such as land and water-resources managers to prevent or minimize harmful impacts on groundwater quality. The focus of the study is to evaluate the quality of groundwater around the Niger Delta Basin Development Authority in Nigeria and assess the aquifer characteristics and its vulnerability to contamination About hundred (100) boreholes spread to cover the study area were sampled. The water samples were analyzed using standard procedures for assessing drinking water qualities in order to understand the existing condition of groundwater quality within the study area. In addition, existing borehole logs were acquired and lithological mapping of the study area was done to acquire relevant data that was needed to generate thematic maps such as; depth to groundwater map, aquifer recharge map, aquifer media map, soil media map, hydraulic conductivity map and the vadose zone map. The topographic map of the study area was generated from the digital elevation model (DEM). To generate the groundwater contamination map, pairwise overlay analysis using geographic information systems (GIS) was employed.Based on the final DRASTIC map, it was observed that most of the locations from where water samples were collected fell within the light brown colouration with computed DRASTIC index of between (140-160) indicating high rate of vulnerability of the aquifer to contamination.
\end{abstract}

Keywords: DRASTIC, Groundwater quality, Lithological mapping, Overlay analysis, Aquifer media.

DOI: $10.7176 / \mathrm{IKM} / 9-11-05$

Publication date: December $31^{\text {st }} 2019$

\section{Introduction}

Groundwater is one of the major sources of water. Groundwater is water stored under the earth surface in rocks and soil segments called aquifers and is less susceptible to contamination by the action of microorganism (Debels, et al., 2005). As groundwater use has increased, issue associated with the quality of groundwater resources have likewise grown in importance. Groundwater, depending on the depth and the prevailing soil condition is vulnerable to pollution by anthropogenic activities, such as agricultural sources, urbanization, unengineered disposal of wastes including de-icing salt, oil and chemical spillage (Baalousha, 2010). Groundwater, once polluted can be very difficult to remediate back to its natural pristine state. To effectively and properly protect groundwater, it is crucial being able to identify areas where groundwater may be most vulnerable to contamination and translate this information into vulnerability maps that can be used by potential end-users, such as land and water-resources managers, to prevent or minimize harmful impacts on groundwater quality (Houan et al., 2012). To this end, various methods, based on different approaches and using diverse input parameters, have been developed to perform groundwater vulnerability assessment. However, in order to be considered an effective tool to be used in environmental planning and management, the end products of such methods (i.e., groundwater vulnerability maps) should be sound scientifically, meaningful and reliable (Kazakis and Voudouris, 2011). In fact, a groundwater vulnerability map must allow taking scientifically defensible decision to protect groundwater resources. In addition, it must represent the study area through a limited number of vulnerability classes consenting to meet policy and management objectives and must depict the actual spatial distribution of the contamination in the study area (Gogu and Dassargues, 2000).

Numerous methods exist in the literature for groundwater analysis and contaminant vulnerability assessment. The DRASTIC overlay methods remain the most use method for studies in this area of research. DRASTIC is a groundwater vulnerability model for evaluating the pollution potential of large areas using the hydrogeological settings of the region. This model was developed by the US EPA (US Environmental Protection Agency) in the 1980s (Aller et al. 1987) as a standardized system for evaluating the intrinsic vulnerability of groundwater to pollution. This model employs a numerical ranking system that assigns relative weights to various parameters that help in the evaluation of relative groundwater vulnerability to contamination (Sinanh and Razack 2009). The DRASTIC system considers seven parameters, namely; depth to water (D), net recharge (R), aquifer media (A), soil media (S), topography (T), impact of the vadose zone (I), and hydraulic conductivity of the aquifer $(\mathrm{C})$. The final vulnerability index $(D i)$ is a weighted sum of the seven parameters and can be computed using the formula proposed by Aller et al. 1987. Groundwater vulnerability maps show areas of 
greatest potential for groundwater contamination on the basis of hydrogeologic and anthropogenic (human) factors. Vulnerability maps are thus useful tools in environmental decision-making process. Based on the produced vulnerability map, it is possible to point out priority areas where there is a significant risk of groundwater contamination taking into account the location of different forms of land use classes.

\section{Materials and Methods}

\subsection{Description of study area}

The study area for this research is the Niger Delta Basin Development Authority. This study covers the original area of operation of the River Basin Authority, which is Rivers and Bayelsa State alone. The geographical coordinates of Rivers and Bayelsa states are $4.8581^{\circ} \mathrm{N}$ and $6.9209^{\circ} \mathrm{E}$ and $4.25^{\circ} \mathrm{S}$ and $5.37^{\circ} \mathrm{W}$ and $6.75^{\circ} \mathrm{E}$ respectively (Nwankwoala et al., 2011). The Niger Delta Basin is situated in the south-south geo-political zone of Nigeria. It is located in the rain forest region with relative humidity above $80 \%$ having an annual temperature range of $25^{\circ} \mathrm{C}$ to $31^{\circ} \mathrm{C}$ and annual rainfall of $4700 \mathrm{~mm}$ on the coast to about $2400 \mathrm{~mm}$. The basin is characterized by two alternating climatic conditions of a long period of rainy season spanning from March to November, followed by a dry season spreading from November to March (Nwankwoala, et al., 2011). Figures 1 and 2 shows the Google earth and the study area maps respectively.

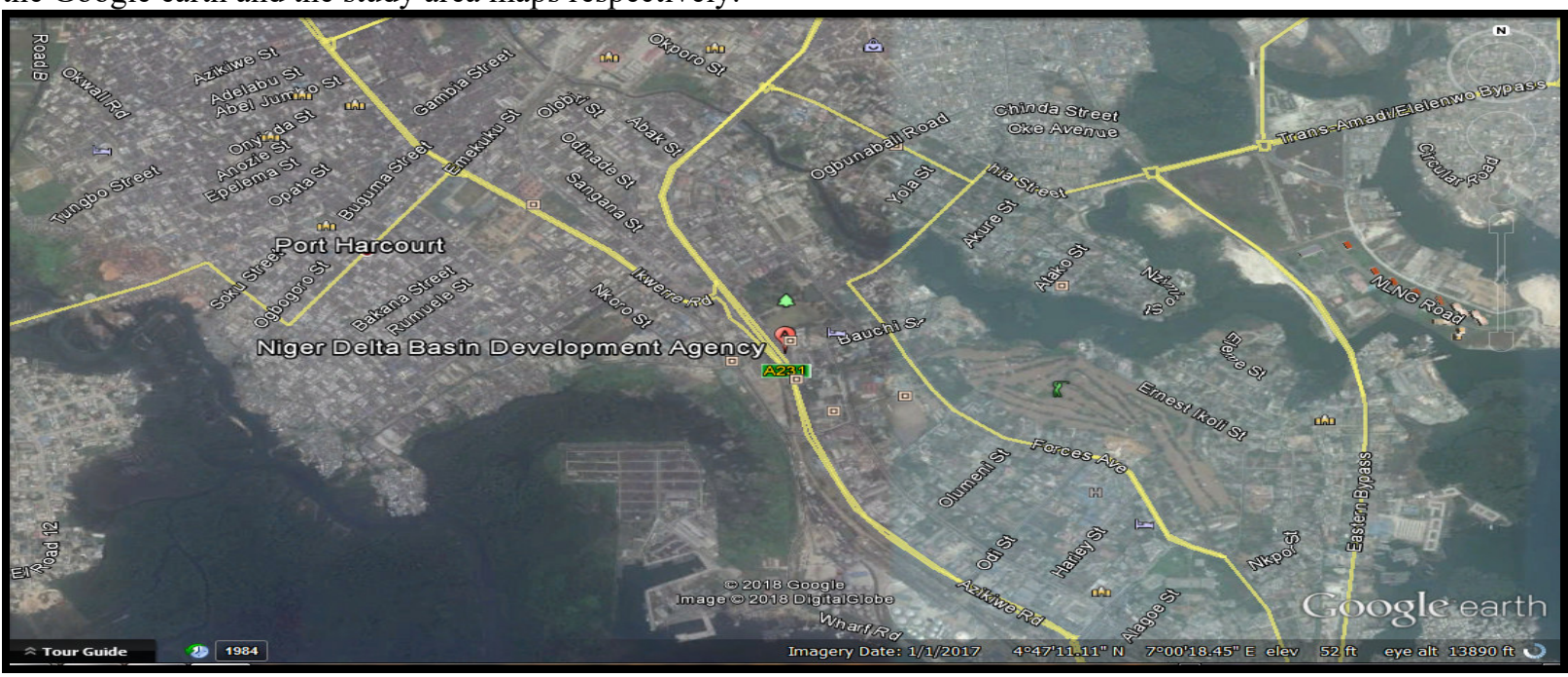

Figure 1: Google earth map of study area (Google .com)

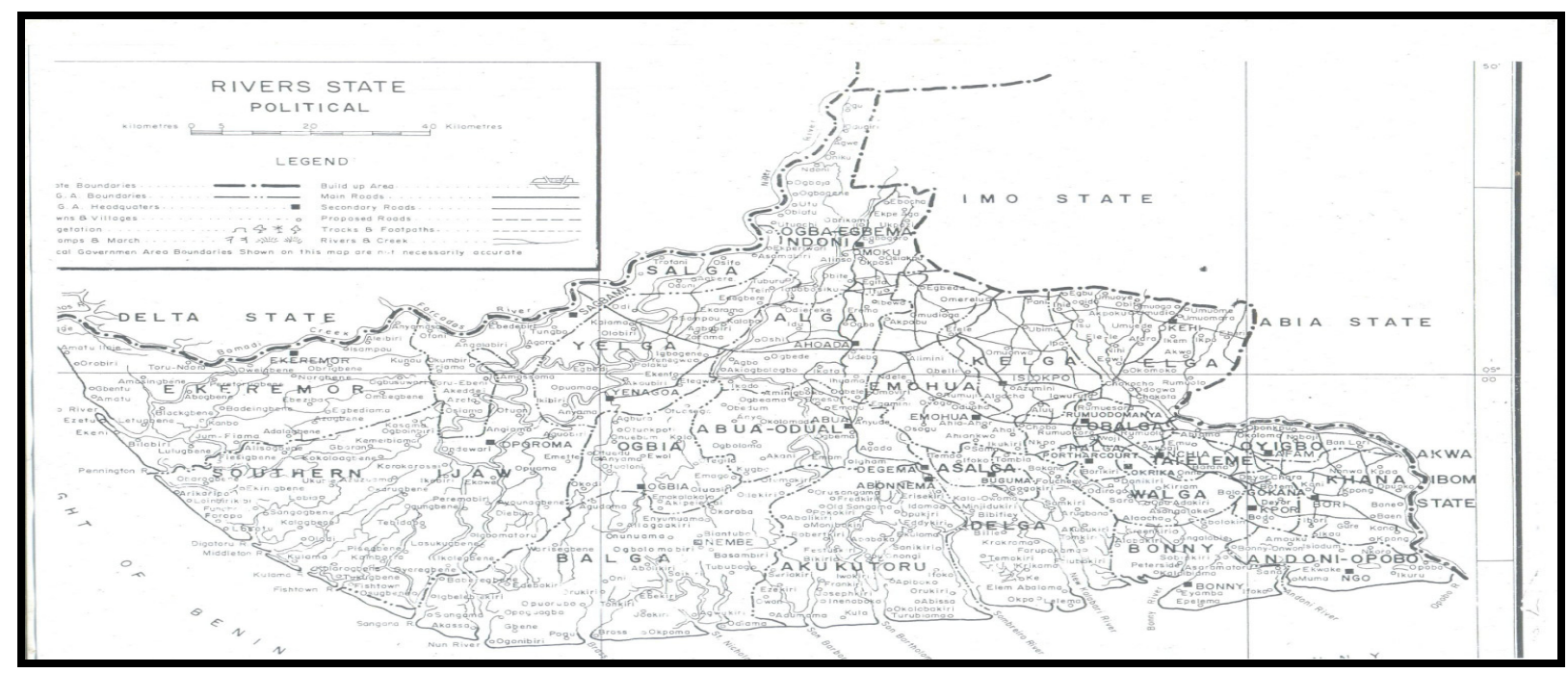

Figure 2: Map of study area ((Bolaji and Tse, 2009)

\subsubsection{Geology and Hydrogeology of study area}

The Niger Delta Basin is located on the continental margin of the Gulf of Guinea in equatorial West Africa. The Niger Delta lithofacies is made up of the three distinct vertical subdivisions viz. the Benin formation, the Agbada formation and the Akata formation. The Benin formation being the upper delta-top Lithofacies comprises of massive continental sands and gravels. The Agbada formation or facie consists of the pro-delta marine shales, with low stand turbidite fans which are deposited in a deep marine setting. In the Northern Delta Sector during 
the Oligocene times the Benin formation first occurs (Bolaji and Tse, 2009). Similarly, Paleocene age was established as the occurrence of the Akata formation in the proximal parts of the Delta. The Niger Delta complex geomorphologic features comprise of fresh water swamps, mangrove swamps, beaches, bars, and estuaries (Bolaji and Tse, 2009).

\subsection{Sampling location and sample collection}

The boundary of built up area (land use) within the study area was digitized and gridded at $2 \mathrm{~km}$ interval to determine the sampling points and ensure uniform coverage. Water samples was collected systematically so as to have a general overview of the water quality condition within the study area. For accurate geo-referencing of the selected boreholes, Garmin hand held GPS receiver was employed to determine the geographical coordinates of each borehole. A section of the boreholes sampled including their location and geographical coordinates is presented in Table 1. One hundred (100) boreholes were systematically sampled with reference to location points at each season: Wet season (July to October 2018) and dry season (November to December 2018) in order to determine the physico-chemical and biological parameters of the groundwater samples. At every point of collection, the air tight, clean and dried plastic containers were rinsed two to three times with the borehole water to be sampled before collection. The samples were labelled properly and stored in air tight, clean and dried plastic containers before been transported to Water Resources and Environmental laboratory in the Department of Civil Engineering, University of Benin were the analysis were conducted in line with standard procedures and guideline recommended by World Health Organization (WHO). The water samples were analyzed in triplicates to obtain the mean value and standard deviation of each water quality test parameters. For the analysis of biochemical oxygen demand (BOD), the black bottles containing the water samples remained tightly closed prior to analysis in order to prevent photosynthetic and oxygen generation. In-situ parameters, namely; dissolved oxygen (DO), temperature, $\mathrm{pH}$ electrical conductivity (EC) and total dissolved solids (TDS) were determined in the field immediately after sample collection to avoid false measurement values (APHA, 2005).

Table 1: Coordinate Data of Sampled Boreholes (RIVERS)

\begin{tabular}{|c|c|c|c|}
\hline Borehole Codes & Locations & Northings & Easting \\
\hline 1. Sample R1 & Igbu Ahaoda & 239820 & 561471 \\
\hline 2. Sample R2 & Mini Ama & 269110 & 525361 \\
\hline 3. Sample R3 & Arukwo-Abua & 235669 & 537656 \\
\hline 4. Sample R4 & Bakana & 286341 & 528043 \\
\hline 5. Sample R5 & Edeoha-Ahoada & 237214 & 556600 \\
\hline 6. Sample R6 & Edeoha-Ahoada & 236203 & 556600 \\
\hline 7. Sample R7 & Okoboh-Abua & 235766 & 540433 \\
\hline 8. Sample R8 & Buguma & 262207 & 524264 \\
\hline 9. Sample R9 & Air force Base & 280557 & 534103 \\
\hline 10. Sample R10 & Trans Amadi & 279389 & 530030 \\
\hline 11. Sample R11 & Ipo-Ikwerre & 274121 & 532098 \\
\hline 12. Sample R12 & Woji & 286716 & 533642 \\
\hline 13. Sample R13 & Rumuokwurushi (1) & 283293 & 536010 \\
\hline 14. Sample R14 & Amakiri Polo & 286238 & 527163 \\
\hline 15. Sample R15 & Rukpokwu & 289003 & 534162 \\
\hline 16. Sample R16 & Aggrey & 280451 & 526634 \\
\hline 17. Sample R17 & NDBDA & 278741 & 529397 \\
\hline 18. Sample R18 & Rumuokwurushi (2) & 283012 & 536068 \\
\hline 19. Sample R19 & Amadi-Ama & 279849 & 530118 \\
\hline 20. Sample R20 & Owodu & 287302 & 531219 \\
\hline 21. Sample R21 & Okochiri & 307314 & 519241 \\
\hline 22. Sample R22 & Trans Amadi (3) & 278023 & 530112 \\
\hline 23. Sample R23 & Railway & 279801 & 527029 \\
\hline 24. Sample R24 & Bundu & 279684 & 525973 \\
\hline 25. Sample R25 & Oyorokoto & 325714 & 496236 \\
\hline 26. Sample R26 & Kono Town & 334047 & 508598 \\
\hline 27. Sample R27 & Oyigbo (1) & 289245 & 538032 \\
\hline 28. Sample R28 & Ngo Town Andoni & 323819 & 495804 \\
\hline 29. Sample R29 & Yegha Gokona & 319044 & 517018 \\
\hline 30. Sample R30 & Oyigbo (2) & 289599 & 538240 \\
\hline 31. Sample R31 & Nyokuru & 339050 & 510170 \\
\hline 32. Sample R32 & Tegu-Gokana & 316831 & 519746 \\
\hline 33. Sample R33 & Woji (2) & 286421 & 533116 \\
\hline
\end{tabular}




\subsection{Water Quality Analysis}

A total of thirty-three (33) physico-chemical parameters and two (2) microbiological parameters were analyzed for each sampled domestic borehole to provide an insight into the overall quality of water within the study area. The physico-chemical parameters include: temperature, odour, colour/clarity, total hydrocarbon content (THC), pH, Electrical conductivity (EC), Turbidity, Total suspended solid (TSS), Salinity, Alkalinity, Total Dissolve Solids (TDS), and Dissolved Oxygen (DO). Others are; Biochemical Oxygen Demand (BOD), Chemical Oxygen Demand (COD), Bicarbonate $\left(\mathrm{HCO}_{3}\right)$, Sodium $(\mathrm{Na})$, Potassium $(\mathrm{K})$, Calcium $(\mathrm{Ca})$, Magnesium $(\mathrm{Mg})$, Chloride $\left(\mathrm{Cl}^{-}\right)$, Phosphorus $(\mathrm{P})$, Ammonium $\left(\mathrm{NH}_{4}\right)$, Nitrite $\left(\mathrm{NO}_{2}\right)$, Nitrate $\left(\mathrm{NO}_{3}\right)$, Sulphate $\left(\mathrm{SO}_{4}\right)$ and heavy metals, namely; Iron (Fe), Manganese $(\mathrm{Mn})$, Zinc $(\mathrm{Zn})$, Copper $(\mathrm{Cu})$, Chromium $(\mathrm{Cr})$, Cadmium $(\mathrm{Cd})$, Nickel (Ni) and Lead $(\mathrm{Pb})$. The microbiological parameters include: Total Coliform Counts (TCC) and E. Coli

\subsubsection{Determination of in-situ parameters; (pH, EC, TDS, DO and Temperature)}

For electrical conductivity (EC), total dissolved solids (TDS), $\mathrm{pH}$, temperature and dissolved oxygen (DO), insitu measurements were carried out since the measurement values of the parameter's changes with storage time (WHO, 2003). pH, electrical conductivity, temperature and total dissolved solids were measured using portable meter's (multi-parameters) while dissolved oxygen was examined using DO meter (Lutron DO-5509, Range 0 20mg/l) shown in Figure 3

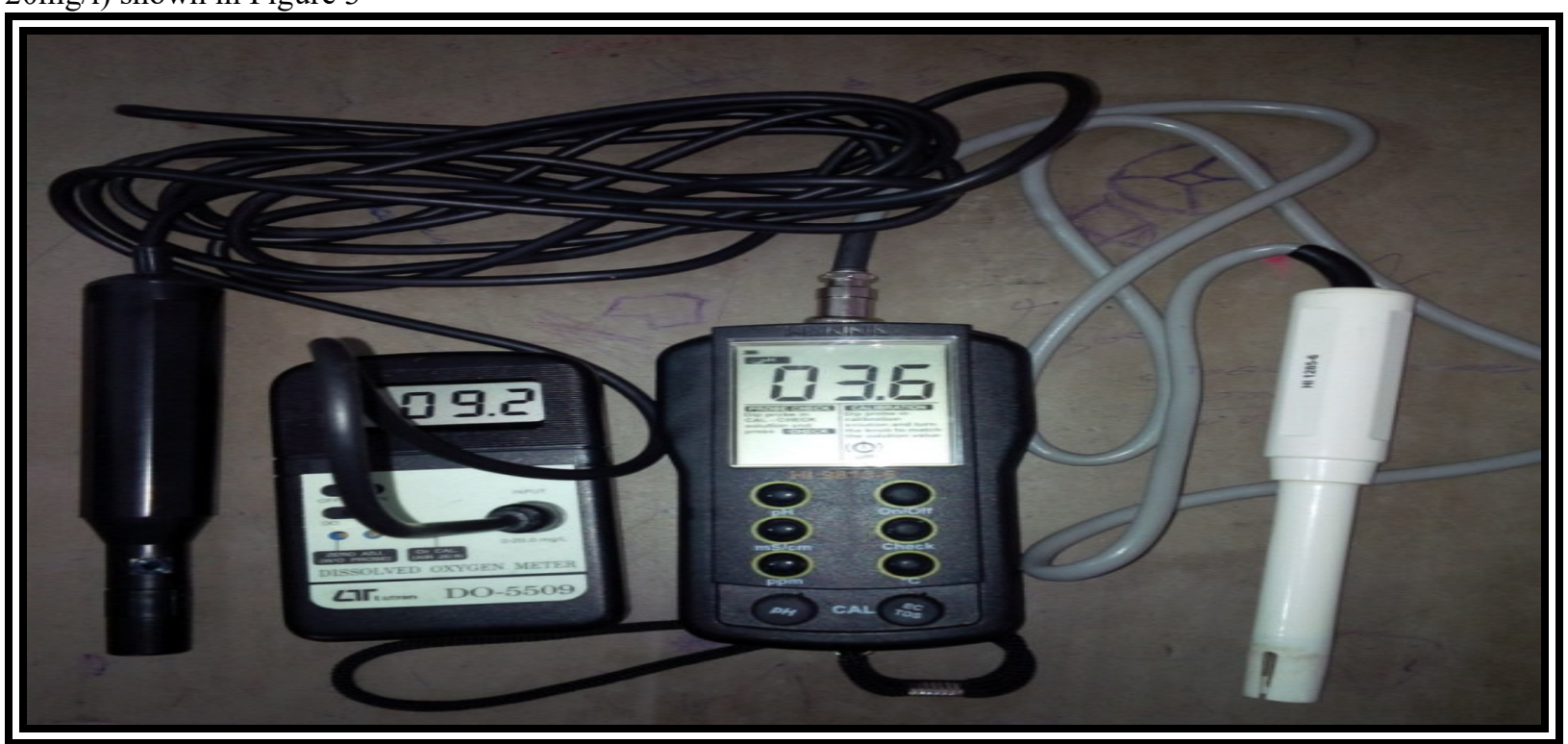

Figure 3: DO meter and multi portable meter

The multi portable meter probe was submerged in the water at $4 \mathrm{~cm}$ and $\mathrm{pH}$ mode selected. Water sample was stirred gently and $\mathrm{pH}$ value displayed on the meter was allowed to adjust and stabilize before recording. Other measurements buttons were pressed successively and values recorded. The procedure was repeated three (3) times and the mean value calculated for each parameter. DO meter was also inserted into the water sample at about $10 \mathrm{~cm}$ depth using the oxygen probe handle.

UNICAM 969 Atomic Absorption Spectrometer (AAS) shown in Figure 4 was used to determine the concentration of heavy metals such as; Iron $(\mathrm{Fe})$, Manganese $(\mathrm{Mn})$, Zinc $(\mathrm{Zn})$, Copper $(\mathrm{Cu}), \mathrm{Chromium}(\mathrm{Cr})$, Cadmium (Cd), Nickel (Ni), Lead ( $\mathrm{Pb}$ ), and Vanadium (V) while UV visible spectrophotometer (Thermo Scientific Spectronic 20D+ ) presented in Figure 5 was used to analyzed the level of phosphorous (P), Nitrate $\left(\mathrm{NO}_{3}\right)$, Nitrite $\left(\mathrm{NO}_{2}\right)$ and Sulphate $\left(\mathrm{SO}_{4}\right)$. Other apparatus utilized included $250 \mathrm{ml}$ separating glass funnels, Cuvette, $10 \mathrm{ml}$ and $50 \mathrm{ml}$ pipette, $250 \mathrm{ml}$ conical flask, $50 \mathrm{ml}$ burette, $25 \mathrm{ml}$ and $50 \mathrm{ml}$ volumetric flask, glass beads, refrigerator, oven and whatman filter paper. 


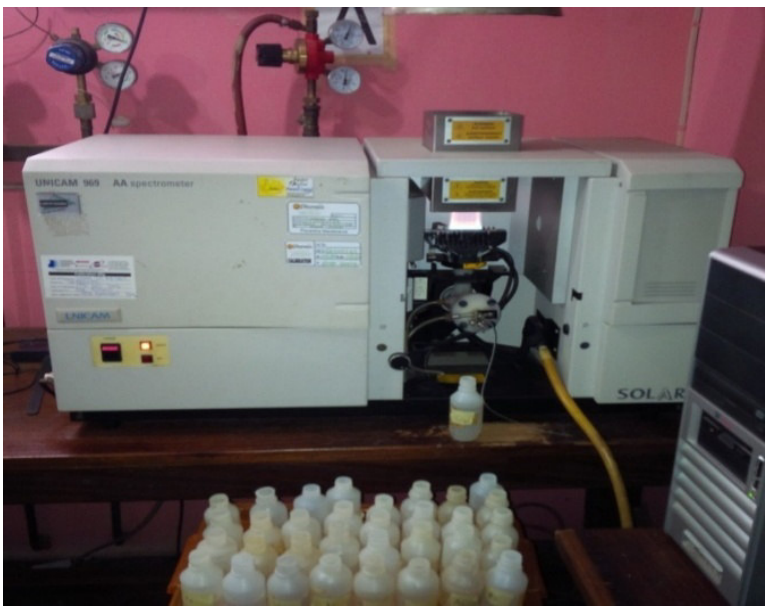

Figure 4: UNICAM 969 AA Spectrometer

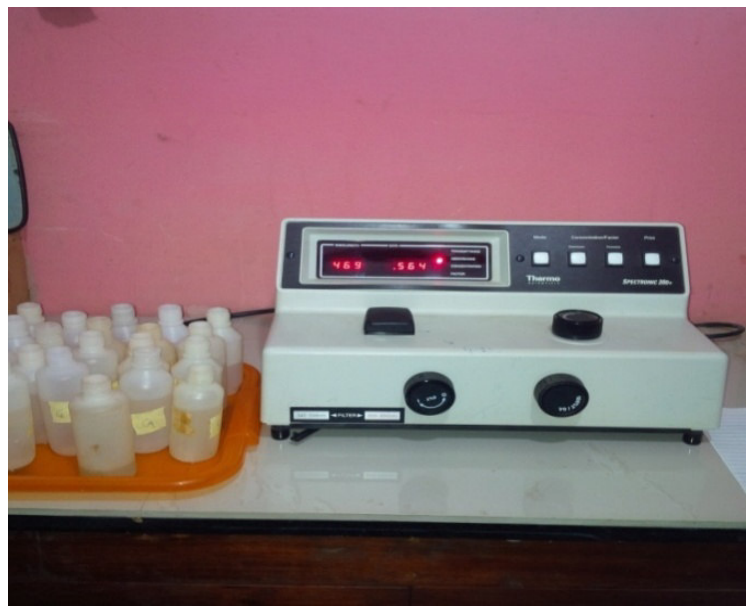

Figure 5: UV Visible Spectrophotometer

Preparation of reagents and procedures employed in the laboratory for the analysis and determination of all water quality parameters followed the standard methods recommended by relevant authorities such as World Health Organization (WHO).

\subsection{Analysis of water quality parameters}

\subsubsection{Water Quality Index Modelling}

Water quality index was calculated for each of the sample water collected from different boreholes for assessing the variation of the overall quality of the water sample at each specific borehole location. The water quality index modelling was done by considering about twenty two (22) important physico-chemical parameters, namely; pH, Nitrate, Electrical conductivity (EC), turbidity, Dissolved Oxygen (DO), total dissolved solids (TDS), Sodium, Lead, Sulphate, Zinc, Copper, Chloride, Iron, Carbonate Hardness, Total Suspended Solids (TSS), Nitrite, Cadmium, Nickel, Total Hydrocarbon Content (THC), Phosphate, Alkalinity and Calcium. The basic steps involved in the modelling of water quality index are as follows:

\subsubsection{Parameter Weightage Determination}

For water quality index calculation, we first have to know the Weightage of each of the parameters identified. Parameters which have higher permissible limits are less harmful because they cannot significantly change the quality of the water sample even when they are present in high concentration. Weightage of tested parameters have an inverse relationship with its permissible limits (Shweta et al., 2013). Therefore

$W_{n}=\frac{1}{S_{n}}$

$\mathrm{W}_{\mathrm{n}}=$ Unit weight of the different parameters tested

$\mathrm{S}_{\mathrm{n}}=$ Standard values of selected parameters (WHO Standard Permissible Limit)

\subsubsection{Quality Rating or Sub Index of Selected Parameters}

Rating scale was prepared for range of values of each parameter. The rating varies from 0 to 100 and is divided into five intervals. The rating $\mathrm{q}_{\mathrm{n}}=0$ implies that the parameter present in water exceeds the standard maximum permissible limits and water is severely polluted. On the other hand, $\mathrm{q}_{\mathrm{n}}=100$ implies that the parameter present in water has the most desirable value. This scale is the modified version of rating scale given by (Shweta et al., 2013) and is calculated as follows:

$q_{n}=\frac{100\left(V_{n}-V_{i o}\right)}{\left(S_{n}-V_{i o}\right)}$

Where:

$\mathrm{q}_{\mathrm{n}}=$ Quality rating or sub index

$\mathrm{V}_{\mathrm{n}}=$ Laboratory test result for each parameter tested

$\mathrm{S}_{\mathrm{n}}=$ Standard value of each parameter tested (WHO standard for drinking water)

$\mathrm{V}_{\mathrm{io}}=$ ideal value of selected parameters tested (in pure water $\mathrm{V}_{\mathrm{io}}=0$ for all parameters tested except $\mathrm{pH}$ and dissolved oxygen which is 7.0 and 14.6 respectively.

\subsubsection{Water Quality Index Calculation}

Essentially, a Water Quality Index (WQI) is a compilation of a number of parameters that can be used to determine the overall quality of water sample. The parameters chosen for the Water Quality Index (WQI) compilation are: $\mathrm{pH}$, Nitrate, Electrical conductivity (EC), turbidity, Dissolved Oxygen (DO), total dissolved solids (TDS), Sodium, Lead, Sulphate, Zinc, Copper, Chloride, Iron, Carbonate Hardness, Total Suspended 
Solids (TSS), Nitrite, Cadmium, Nickel, Total Hydrocarbon Content (THC), Phosphate, Alkalinity and Calcium.. The numerical value was then multiplied by a weighting factor that is relative to the significance of the test to water quality. The sum of the resulting values was added together to arrive at an overall water quality index. It is basically a mathematical means of calculating a single value from multiple test results. The WQI result represents the level of water quality in a given borehole location. The following steps were employed in computing the overall water quality.

i. The weightage unit $\left(\mathrm{W}_{\mathrm{n}}\right)$ for all parameters tested was determined and summed up to obtain $\sum W_{n}$

ii. The quality rating or sub-index for all parameters tested was determined and summed up to obtain $\sum q_{n}$

iii. The index $\mathrm{W}_{\mathrm{n}} * \mathrm{q}_{\mathrm{n}}$ was calculated for each parameter tested and summed up to obtain $\sum W_{n} \cdot q_{n}$

iv. Finally, Water Quality Index (WQI) was computed for each borehole location using the mass balance equation of the form: $(100)-\left(\frac{\sum W_{n} \cdot q_{n}}{\sum W_{n}}\right)$

\subsection{Contaminant vulnerability assessment using DRASTIC Overlay}

To develop the contamination vulnerability assessment map of the study area, the DRASTIC method was employed. The DRASTIC method relies on seven important parameters in the development of the vulnerability map, namely; depth to groundwater, groundwater recharge, aquifer media, soil media, and topography of study area. Others are; impact of vadose zone and hydraulic conductivity of the aquifer. Since the DRASTIC method involves the evaluation and characterization of highly distributed input data, GIS was utilized in data development and processing (Ne'mat Sadeq, 2006).

2.5.1 Input data acquisition for DRASTIC application

Both remotely sensed data and field data were collected for the study area. Table 2 shows some of the data type and source

Table 2: List of some data required for the study

\begin{tabular}{|c|c|c|c|}
\hline $\mathbf{S} / \mathbf{n}$ & Data / Scale & Type & Source /Date \\
\hline 1. & 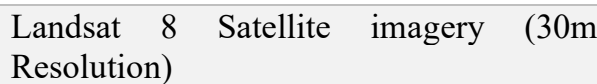 & Remotely sensed & USGS (2016) \\
\hline 2. & SRTM Data (30m DEM Resolution) & Remotely sensed & USGS \\
\hline 3. & Topographical map 1:100,000 & Digital Copy & Federal Survey (1967) \\
\hline 4. & Geological Map $(1: 500,000)$ & Digital copy & $\begin{array}{l}\text { Nigerian Geological survey Agency } \\
(2006)\end{array}$ \\
\hline 5. & Water Table Elevation data & $\begin{array}{l}\text { Geological } \\
\text { Mapping }\end{array}$ & Field Data \\
\hline
\end{tabular}

\subsubsection{Data generation for DRASTIC overlay}

2.5.2.1 Depth to groundwater

Depth to groundwater was obtained from the water table elevation data of the individual wells and the ground surface elevation data at well location. Ground surface elevation at each well location was obtained from the digital elevation model (DEM) of the study area. GIS capability in interpolation was employed to map the depth to groundwater table for the study area (Ne'mat Sadeq, 2006).

\subsubsection{Recharge}

Groundwater recharge was estimated using the equations developed by Guttman (1998) as follows:

For rainfall $<300 \mathrm{~mm} / \mathrm{yr} \rightarrow$ recharge $=0.15 \times$ [precipitation]

For rainfall $\geq 300$ and $\leq 650 \mathrm{~mm} / \mathrm{yr} \rightarrow$ recharge $=0.534 \times$ [precipitation -216$]$

For rainfall $>650 \mathrm{~mm} / \mathrm{yr} \rightarrow$ recharge $=0.8 \times$ [precipitation -360 ]

In order to implement the above equations, rainfall data were prepared for selected stations within the study area. A shape file of the rainfall stations was then created for each station and the average long-term rainfall was computed. Thereafter, Thiessen polygon was created for the stations to develop the areas of constant rainfall which was thereafter processed using GIS extension.

\subsubsection{Aquifer Media}

In order to assess the impact of the aquifer media on the vulnerability to groundwater resources, a lithological mapping of the study area was done and a GIS shape file that provides the distribution of the subsurface media lithology was created.

\subsubsection{Soil Media}

The soil map which shows the nature of soil that dominates the study area was created and utilized for the 
assessment of the soil impact on the overall vulnerability of groundwater resources to contamination. The map was employed to visualize the soil types and their textural characteristics

\subsubsection{Topography}

The topography in the DRASTIC method implies the slope of the ground surface in percentage. In order to compute the slope, the DEM of the study area was used within the GIS environment. The geological units that under-lay the study area was digitized alongside the settlement and geographical features using the topographical map, a final geological and topographical map of the study area was then created.

\subsubsection{Impact of Vadose Zone}

The impact of vadose zone represents the influence of the unsaturated zone on the vulnerability of groundwater resources to contamination. Since we may not have specific information regarding the media of the vadose zone, we assumed that the unsaturated zone is a continuation and extension of the aquifer media and thus the same GIS shape file used in characterizing the impact of the aquifer was also used according to (Ne'mat Sadeq, 2006).

\subsubsection{Hydraulic Conductivity}

In order to assess the impact of aquifer hydraulic conductivity on the overall groundwater vulnerability to contamination, the GIS shape file of the aquifer media was also utilized according to (Ne'mat Sadeq, 2006).

\subsubsection{Generation of Groundwater vulnerability assessment map using GIS}

In order to arrive at a final Groundwater vulnerability assessment map of the study area, the following thematic maps (depth to groundwater map, groundwater recharge map, and aquifer media map, soil media map, and topography map, impact of vadose zone and hydraulic conductivity map of the aquifer) were overlaid using weighted overlay analysis. Weighted overlay analysis is a simple and straightforward method for a combined analysis of multi class maps. The methodology for the overlay analysis is presented in accordance to the works Ne'mat Sadeq, 2006 as follows;

i. Each parameter map was converted to raster data.

ii. Each raster data set was stacked on each other and the weighted overlay analysis was applied in Arc map.

iii. A final Groundwater vulnerability assessment map was thereafter produced

\section{Results and Discussion}

\subsection{Descriptive statistics of groundwater quality parameters}

The descriptive statistics of the water quality parameters which include; the range, minimum value, maximum value, mean, standard deviation, variance, skewness and kurtosis for both the wet season and dry season is presented in Tables 3 and 4 respectively.

Table 3: Descriptive statistics of water quality parameters for wet season

\begin{tabular}{|c|c|c|c|c|c|c|c|}
\hline \multicolumn{2}{|c|}{ Valid N (listwise) } & \multicolumn{2}{|l|}{100} & \multirow[b]{2}{*}{$\begin{array}{c}\text { Std. } \\
\text { Deviation } \\
\end{array}$} & \multirow[b]{2}{*}{ Variance } & \multirow[b]{2}{*}{ Skewness } & \multirow[b]{2}{*}{ Kurtosis } \\
\hline Parameters & Minimum & Maximum & Mean & & & & \\
\hline $\mathrm{pH}$ & 4.1 & 6.8 & 5.376 & 0.63183555 & 0.399216 & $\begin{array}{c}- \\
0.23402061 \\
\end{array}$ & -0.74072 \\
\hline Nitrate (NO3) & 10.12 & 45.66 & 23.6777 & 7.082085074 & 50.15593 & 0.66481299 & 0.471708 \\
\hline $\begin{array}{c}\text { Electrical } \\
\text { Conductivity }\end{array}$ & 10 & 420 & 236.5795 & 79.7857352 & 6365.764 & $\begin{array}{c}- \\
0.17834948\end{array}$ & -0.38415 \\
\hline Turbidity & 0 & 3.2 & 0.07993 & 0.372558944 & 0.1388 & 6.86046398 & 52.3728 \\
\hline $\begin{array}{l}\text { Dissolved } \\
\text { Oxygen }\end{array}$ & 3.8 & 4.5 & 4.145 & 0.132859005 & 0.017652 & 0.36028582 & -0.24443 \\
\hline $\begin{array}{c}\text { Total Dissolved } \\
\text { Solids }\end{array}$ & 6.67 & 277.2 & 109.2603 & 42.50061351 & 1806.302 & 1.53905399 & 3.573946 \\
\hline Sodium & 17.83 & 184.5 & 53.6573 & 27.07022722 & 732.7972 & 2.29824783 & 8.858071 \\
\hline Lead $(\mathrm{Pb})$ & 0 & 0.08 & 0.010858 & 0.008232348 & $6.78 \mathrm{E}-05$ & 5.96404732 & 50.66471 \\
\hline Sulphate & 21.77 & 134.7 & 75.1899 & 27.24220554 & 742.1378 & 0.35741556 & -0.79781 \\
\hline Zinc (Zn) & 1.76 & 3.11 & 2.3805 & 0.289703349 & 0.083928 & 0.42419915 & -0.48188 \\
\hline Copper $(\mathrm{Cu})$ & 1.02 & 2.13 & 1.46053 & 0.300070142 & 0.090042 & 0.24463075 & -0.88103 \\
\hline Chloride (Cl-) & 11.04 & 94.05 & 27.2804 & 11.13387668 & 123.9632 & 2.8678378 & 14.57709 \\
\hline Iron $(\mathrm{Fe})$ & 0.11 & 1.65 & 0.96533 & 0.147416201 & 0.021732 & $\begin{array}{c}- \\
1.05615686 \\
\end{array}$ & 15.07147 \\
\hline Carbonate & 45.67 & 192.1 & 111.8168 & 35.37305897 & 1251.253 & 0.28541766 & -0.15832 \\
\hline $\begin{array}{c}\text { Total Suspended } \\
\text { Solids }\end{array}$ & 0 & 5.61 & 0.10048 & 0.610993122 & 0.373313 & 8.09003419 & 69.82273 \\
\hline Nitrite (NO2) & 0 & 0.437 & 0.1235 & 0.114547815 & 0.013121 & 0.7630461 & -0.6274 \\
\hline
\end{tabular}




\begin{tabular}{|c|c|c|c|c|c|c|c|}
\hline \multicolumn{7}{|c|}{ Valid N (listwise) } \\
\hline Parameters & Minimum & Maximum & Mean & $\begin{array}{c}\text { Std. } \\
\text { Deviation }\end{array}$ & Variance & Skewness & Kurtosis \\
\hline Cadmium (Cd) & 0 & 0 & 0 & 0 & 0 &. & \\
\hline Nickel (Ni) & 0 & 0.01 & 0.00054 & 0.00110481 & $1.22 \mathrm{E}-06$ & 6.5004899 & 54.74305 \\
\hline $\begin{array}{c}\text { Total } \\
\text { Hydrocarbon }\end{array}$ & 0 & 0.12 & 0.00909 & 0.021765553 & 0.000474 & 3.90649499 & 15.62882 \\
\hline $\begin{array}{c}\text { Phosphate } \\
\text { (PO4) }\end{array}$ & 3.07 & 32.04 & 6.81685 & 3.810289242 & 14.5183 & 3.73971415 & 20.07459 \\
\hline $\begin{array}{c}\text { Temperature } \\
\text { Resistivity }\end{array}$ & 27.9 & 29.2 & 28.512 & 0.274608997 & 0.07541 & 0.25331229 & -0.79825 \\
\hline Alkalinity & 23.4 & 172.3 & 104.6677 & 38.44492487 & 1478.012 & 0.006685 & -1.00267 \\
\hline Salinity & 2.07 & 23.4 & 5.0239 & 3.618964329 & 13.0969 & 3.52935275 & 13.51332 \\
\hline Chromium (Cr) & 0 & 0.001 & 0.00001 & 0.0001 & $1 \mathrm{E}-08$ & 10 & 100 \\
\hline $\begin{array}{c}\text { Manganese } \\
\text { (Mn) }\end{array}$ & 0 & 0.037 & 0.01603 & 0.007801133 & $6.09 \mathrm{E}-05$ & 0.55154467 & 0.729931 \\
\hline $\begin{array}{c}\text { Magnesium } \\
\text { (Mg) }\end{array}$ & 13.56 & 103.3 & 65.4174 & 19.31053309 & 372.8967 & 0.52054708 & -0.20079 \\
\hline $\begin{array}{c}\text { Potassium (K) } \\
\text { Total Coliform } \\
\text { Count }\end{array}$ & 6.32 & 122.1 & 60.2389 & 24.87519225 & 618.7752 & 0.15362326 & 0.156486 \\
\hline $\begin{array}{c}\text { Calcium } \\
\text { Pand }\end{array}$ & 3.07 & 98.99 & 52.6568 & 18.1554804 & 329.6215 & 0.43191196 & 0.754687 \\
\hline
\end{tabular}

Table 4: Descriptive statistics of water quality parameters for dry season

\begin{tabular}{|c|c|c|c|c|c|c|c|}
\hline Parameters & Minimum & Maximum & Mean & $\begin{array}{c}\text { Std. } \\
\text { Deviation }\end{array}$ & Variance & Skewness & Kurtosis \\
\hline $\mathrm{pH}$ & 4.25 & 10.05 & 6.6786 & 1.096971976 & 1.203348 & 0.05232207 & 0.712023 \\
\hline Nitrate (NO3) & 0 & 16.07 & 1.367972 & 2.810731484 & 7.900211 & 3.56769646 & 14.6331 \\
\hline $\begin{array}{c}\text { Electrical } \\
\text { Conductivity }\end{array}$ & 0.02 & 938 & 123.073 & 137.5568643 & 18921.89 & 3.17679825 & 14.06649 \\
\hline Turbidity & 0 & 387 & 17.93173 & 58.76592774 & 3453.434 & 4.20437275 & 19.37667 \\
\hline $\begin{array}{l}\text { Dissolved } \\
\text { Oxygen }\end{array}$ & 4.2 & 4.8 & 4.5931 & 0.107559662 & 0.011569 & $\begin{array}{c}- \\
0.75589181\end{array}$ & 0.872339 \\
\hline $\begin{array}{c}\text { Total Dissolved } \\
\text { Solids }\end{array}$ & 0 & 715 & 71.5043 & 102.2128628 & 10447.47 & 3.87096416 & 18.86167 \\
\hline Sodium & 0 & 43.1 & 11.68009 & 8.604944145 & 74.04506 & 0.56939918 & 0.30702 \\
\hline Lead $(\mathrm{Pb})$ & 0 & 0.003 & 0.00011 & 0.000423907 & $1.8 \mathrm{E}-07$ & 4.7353108 & 25.58794 \\
\hline Sulphate & 0 & 64 & 2.074368 & 8.586736135 & 73.73204 & 6.48073459 & 42.4997 \\
\hline Zinc $(\mathrm{Zn})$ & 0 & 3.04 & 1.0576 & 0.6533173 & 0.426823 & 0.14154585 & 0.229859 \\
\hline Copper $(\mathrm{Cu})$ & 0 & 1.24 & 0.35542 & 0.45894143 & 0.210627 & 0.60722938 & -1.52427 \\
\hline Chloride (Cl-) & 0 & 440 & 25.3935 & 51.65349983 & 2668.084 & 6.0409957 & 43.48021 \\
\hline Iron $(\mathrm{Fe})$ & 0 & 18.4 & 0.70944 & 2.669714184 & 7.127374 & 4.94520205 & 26.00851 \\
\hline Carbonate & 0 & 268.4 & 39.9228 & 50.26808703 & 2526.881 & 2.03726526 & 4.740594 \\
\hline $\begin{array}{c}\text { Total Suspended } \\
\text { Solids } \\
\end{array}$ & 0 & 75.8 & 3.14937 & 13.20623594 & 174.4047 & 4.70402936 & 21.46297 \\
\hline Nitrite (NO2) & 0 & 0.1 & 0.00325 & 0.01509189 & 0.000228 & 5.75933442 & 34.1843 \\
\hline Cadmium $(\mathrm{Cd})$ & 0 & 0 & 0 & 0 & 0 & & . \\
\hline Nickel (Ni) & 0 & 0.001 & 0.00003 & 0.000171447 & $2.94 \mathrm{E}-08$ & 5.59464946 & 29.89777 \\
\hline $\begin{array}{c}\text { Total } \\
\text { Hydrocarbon } \\
\end{array}$ & 0 & 0.0045 & 0.001327 & 0.000997963 & $9.96 \mathrm{E}-07$ & 0.88835571 & 0.65732 \\
\hline $\begin{array}{c}\text { Phosphate } \\
\text { (PO4) }\end{array}$ & 0 & 6.71 & 2.41391 & 1.338253974 & 1.790924 & 0.94015078 & 1.089003 \\
\hline Temperature & 22.32 & 29.9 & 27.7152 & 1.219667516 & 1.487589 & $\begin{array}{c}- \\
0.97297169 \\
\end{array}$ & 2.988244 \\
\hline
\end{tabular}




\begin{tabular}{|c|c|c|c|c|c|c|c|}
\hline Parameters & Minimum & Maximum & Mean & $\begin{array}{c}\text { Std. } \\
\text { Deviation }\end{array}$ & Variance & Skewness & Kurtosis \\
\hline Resistivity & 0.0002 & 0.235 & 0.004863 & 0.023692903 & 0.000561 & 9.47416621 & 92.47853 \\
\hline Alkalinity & 0 & 284 & 59.6301 & 69.70132157 & 4858.274 & 1.52535287 & 1.653901 \\
\hline Salinity & 0 & 94.7 & 1.1399 & 9.461594725 & 89.52177 & 9.96463919 & 99.51802 \\
\hline Chromium (Cr) & 0 & 0.001 & 0.00001 & 0.0001 & $1 \mathrm{E}-08$ & 10 & 100 \\
\hline $\begin{array}{c}\text { Manganese } \\
(M n)\end{array}$ & 0 & 23.04 & 0.26091 & 2.320648416 & 5.385409 & 9.76398749 & 96.55996 \\
\hline $\begin{array}{c}\text { Magnesium } \\
(M g)\end{array}$ & 0 & 80 & 6.30379 & 12.0187128 & 144.4495 & 4.71240266 & 25.201 \\
\hline Potassium (K) & 1.004 & 34.05 & 10.24324 & 7.974013292 & 63.58489 & 0.80373057 & -0.00769 \\
\hline $\begin{array}{c}\text { Total Coliform } \\
\text { Count }\end{array}$ & 0 & 1800 & 83.88003 & 354.8020085 & 125884.5 & 4.6591558 & 20.40926 \\
\hline Calcium & 0 & 250 & 18.3696 & 30.93978048 & 957.27 & 5.28751972 & 34.50283 \\
\hline
\end{tabular}

From the result of Table 3 and 4, it was observed that $\mathrm{pH}$ ranges from 2.7 for wet season to 5.8 during the dry season. The observable minimum and maximum $\mathrm{pH}$ during wet and dry season were (4.1 and 6.8) for wet season and (4.25 to 10.05) for dry season. The mean $\mathrm{pH}$ for wet season was 5.376 while for dry season, the mean $\mathrm{pH}$ was 6.6786. The observed standard deviation of $\mathrm{pH}$ for wet season was 0.632 with variance of 0.399 . During the dry season, standard deviation was observed to be 1.097 with a variance of 1.203 . Using the ratio of standard deviation to mean, coefficient of variability $(\mathrm{CV})$ was calculated in other to evaluate the variation of $\mathrm{pH}$ for both wet and dry season. For wet season the coefficient of variation was 0.118 while for dry season, the variation was 0.164 . The observed difference in the computed coefficient of variation accounted for the influence of season on the $\mathrm{pH}$ of groundwater within the study area. The trend of high $\mathrm{pH}$ observed during the wet season could be trace to the washing of hydrocarbon components by runoff and the subsequent infiltration of these components into the underlying aquifer. During the dry season, these hydrocarbon components are vaporized by the effect of heat due to high temperature resulting to less infiltration thereby increasing the $\mathrm{pH}$ of groundwater. In a study by (Sisodia and Moundiotiya, 2006), the author claimed that high $\mathrm{pH}$ during the dry season can be attributed to high temperature which enhances microbial activities. This submission can also apply to the basin authority which is constantly under threat due to environmental degradation occasioned by oil spillage.

From the result of Table 3 and 4, it was observed that total dissolved solids (TDS) ranges from $270.52 \mathrm{mg} / 1$ for wet season to $715.0 \mathrm{mg} / \mathrm{l}$ during the dry season. The observed minimum and maximum tds during wet and dry season are $(6.67 \mathrm{mg} / 1$ and $277.2 \mathrm{mg} / 1)$ for wet season and $(0$ and $715.0 \mathrm{mg} / \mathrm{l})$ for dry season. The mean tds for wet season was 109.26 while for dry season, the mean tds was 71.504 . The observed standard deviation of tds for wet season was 42.30 with variance of 1806.3 . During the dry season, standard deviation was observed to be 102.213 with a variance of 10447.47 . Using the ratio of standard deviation to mean, coefficient of variability (CV) was calculated in other to evaluate the variation of tds for both wet and dry season. For wet season the coefficient of variation was 0.38898 while for dry season, the variation was 1.42947 . The observed difference in the computed coefficient of variation accounted for the influence of season on total dissolved solids of groundwater within the study area. The higher value of CV during the dry season can be traced to increased activities of oil companies during the dry season compared to wet season.

From the result of Table 3 and 4, it was observed that electrical conductivity (EC) ranges from $410 \mu \mathrm{s} / \mathrm{cm}$ for wet season to $937.98 \mu \mathrm{s} / \mathrm{cm}$ during the dry season. The observed minimum and maximum EC during wet and dry season are $(10 \mu \mathrm{s} / \mathrm{cm}$ and $420 \mu \mathrm{s} / \mathrm{cm})$ for wet season and $(0.02 \mu \mathrm{s} / \mathrm{cm}$ and $938.0 \mu \mathrm{s} / \mathrm{cm})$ for dry season. The mean EC for wet season was 236.58 while for dry season, the mean EC was 123.07. The observed standard deviation of EC for wet season was 79.79 with variance of 6365.70 . During the dry season, standard deviation was observed to be 137.56 with a variance of 18921.89 . Using the ratio of standard deviation to mean, coefficient of variability (CV) was calculated in other to evaluate the variation of $\mathrm{EC}$ for both wet and dry season. For wet season the coefficient of variation was 0.3373 while for dry season, the variation was 1.1177 . The observed difference in the computed coefficient of variation accounted for the influence of season on electrical conductivity of groundwater within the study area. The higher value of coefficient of variability observed during the dry season can also be traced to increased activities of oil companies during the dry season compared to wet season.

From the result of Table 3 and 4, it was observed that total hydrocarbon content (THC) ranges from $0.12 \mathrm{mg} / \mathrm{l}$ for wet season to $0.0045 \mathrm{mg} / \mathrm{l}$ during the dry season. The observed minimum and maximum THC during wet and dry season are $(0$ and $0.12 \mathrm{mg} / \mathrm{l})$ for wet season and $(0$ and $0.0045 \mathrm{mg} / 1)$ for dry season. The mean THC for wet season was 0.0091 while for dry season, the mean THC was $0.001327 \mathrm{mg} / \mathrm{l}$. The observed standard deviation of THC for wet season was 0.0218 with variance of 0.000474 . During the dry season, standard deviation was observed to be 0.000998 with a variance of $9.96 \mathrm{E}-07$. Using the ratio of standard deviation to 
mean, coefficient of variability $(\mathrm{CV})$ was calculated in other to evaluate the variation of THC for both wet and dry season. For wet season the coefficient of variation was 2.3956 while for dry season, the variation was 0.75207. The observed difference in the computed coefficient of variation accounted for the influence of season on total hydrocarbon content of groundwater within the study area.

Magnesium is one of the most common minerals that make water hard. The higher concentrations of magnesium values recorded during wet season could be due to dissolution of sedimentary rock (Vasanthavigar et al., 2010). Generally, magnesium maintains equilibrium in most waters (Ishaku et al., 2011). From the result of Table 4.1 and 4.2 , it was observed that magnesium concentration ranges from $89.74 \mathrm{mg} / 1$ for wet season to $80 \mathrm{mg} / \mathrm{l}$ during the dry season. The observed minimum and maximum concentration of magnesium during wet and dry season are $(13.56 \mathrm{mg} / \mathrm{l}$ and $103.30 \mathrm{mg} / \mathrm{l})$ for wet season and $(0$ and $80 \mathrm{mg} / \mathrm{l})$ for dry season. The mean concentration of magnesium for wet season was 65.42 while for dry season, the mean concentration of magnesium was 6.304. The observed standard deviation of magnesium for wet season was 19.311 with variance of 372.90. During the dry season, standard deviation of magnesium was observed to be 12.0187 with a variance of 144.45. Using the ratio of standard deviation to mean, coefficient of variability (CV) was calculated in other to evaluate the variation of magnesium for both wet and dry season. For wet season the coefficient of variation was 0.2952 while for dry season, the variation was 1.90651 . The observed difference in the computed coefficient of variation accounted for the influence of season on the concentration of magnesium of groundwater within the study area.

In general, the concentrations of most parameters were higher during wet season than dry season. This may be due to precipitation, infiltration, leaching and seepage of organic substances, agricultural wastes, industrial effluents, hydrocarbons, domestic sewage, dissolved gases and chemical compounds into underlying aquifer thereby polluting the groundwater.

\subsection{Comparison of water quality parameters with WHO standard}

The results of measured concentrations of each borehole parameters were compared with the standard permissible limits recommended by World Health Organization (WHO) in other to identify the specific borehole parameters that fell within the permissible limit for drinking water standards. Results of the comparisons were obtained in the form of a plot and presented in Figures $6 \mathrm{a}, 6 \mathrm{~b}$ and $6 \mathrm{c}$ respectively.

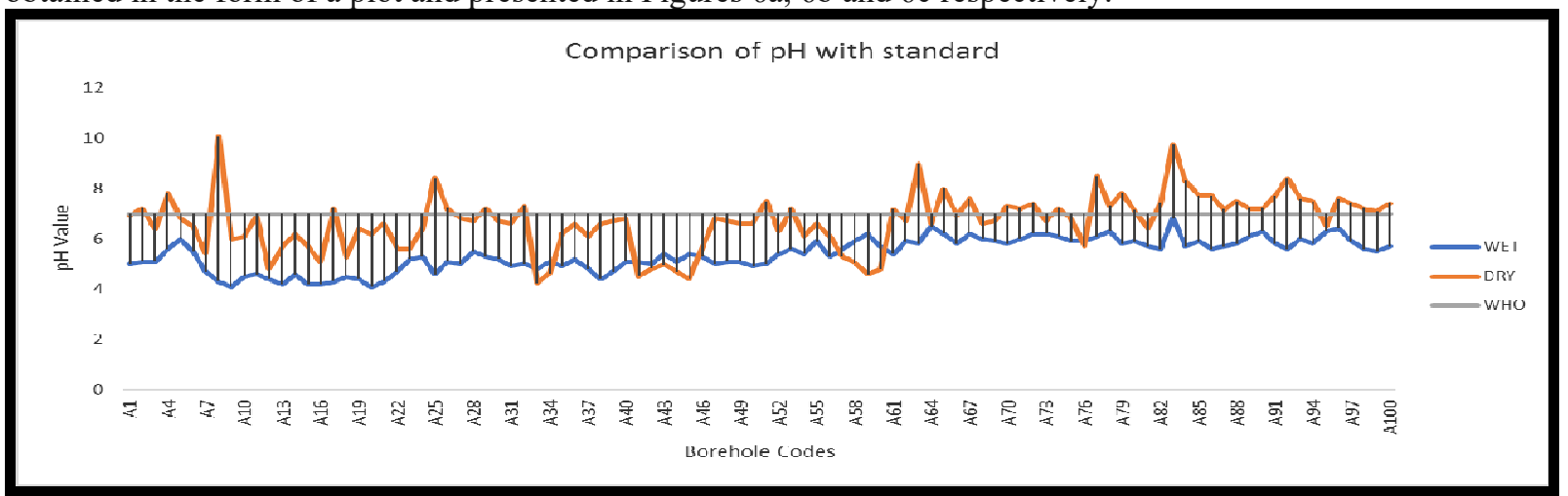

Figure 6a: Comparing the pH of the sampled boreholes with World Heath Organization standard

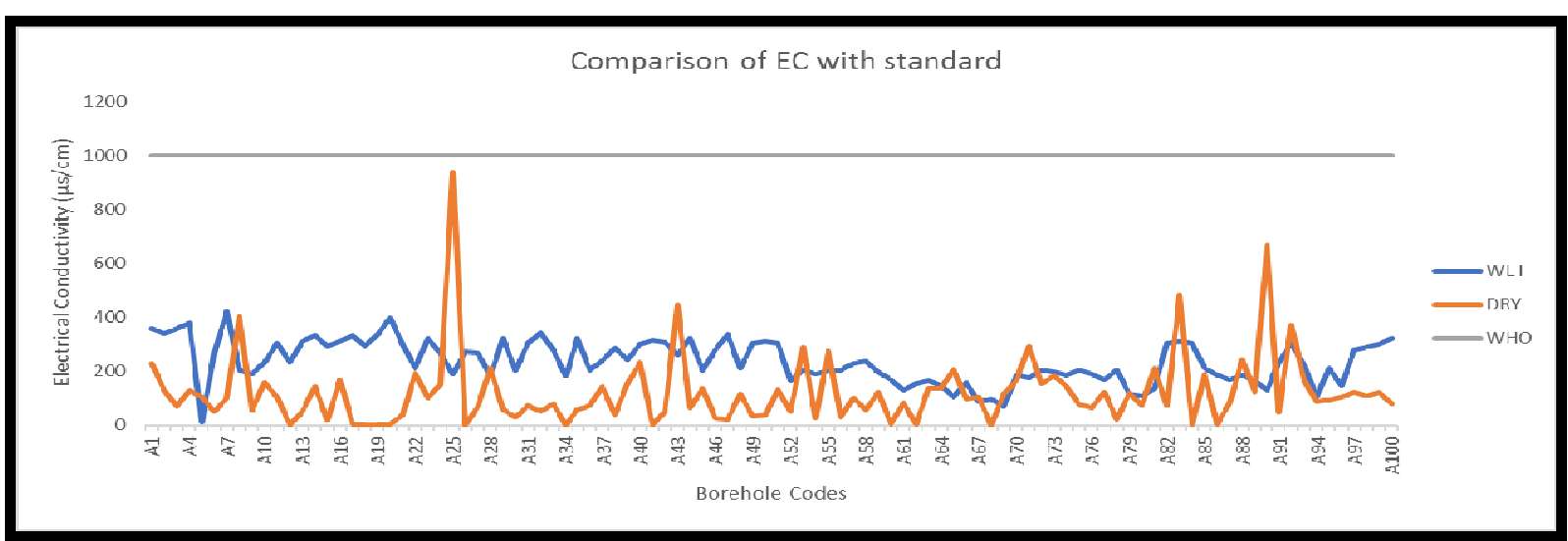

Figure 6b: Comparing the EC of the sampled boreholes with World Heath Organization standard 


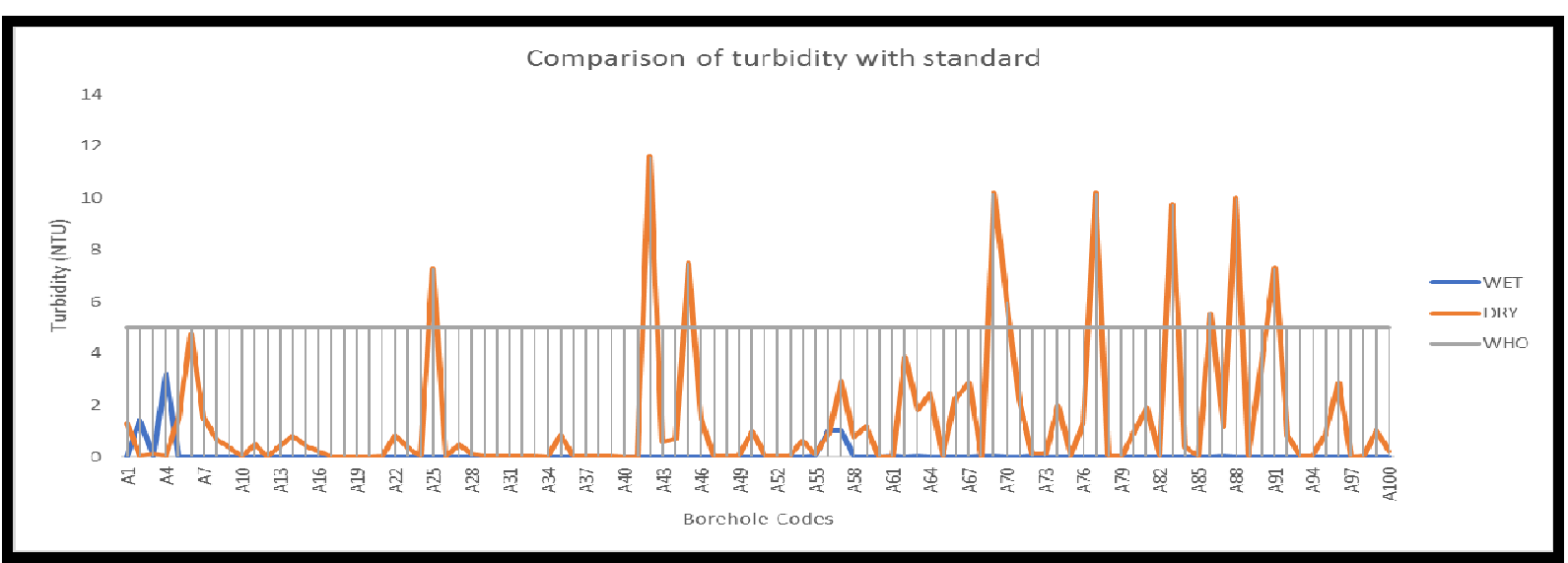

Figure 6c: Comparing the turbidity of the sampled boreholes with World Heath Organization standard

\subsection{Generation of Contaminant Vulnerability Map}

The key assumptions employed in the generation of contaminant vulnerability map of the study area are as follows;

i. Contamination occurs at the ground surface.

ii. The contaminant enters the water table when rain falls on the surface and percolates into the saturated zone.

iii. The contaminant travels with water, at the same rate as water.

iv. The aquifer is unconfined (the method can be modified for a confined aquifer).

v. The dominant pollutants are not pesticides (the method can be modified to include pesticides).

Based on the drastic index (DI) values, a groundwater vulnerability map can be produced using the geographic information system (GIS). Highest or lowest vulnerability values obtained depending on the area covered will be linked with whether the aquifer is shallow or deep, with or without depth of the vadose zone. Basically, the DRASTIC method of groundwater vulnerability assessment employs the different type of maps to obtain a final vulnerability map; the maps include; depth to water tables map (D), net recharge map (R), aquifer media map (A), soil map (S), topography map (T), impact of vadose zone map (I), and hydraulic conductivity map of aquifer $(\mathrm{C})$. The maps description and the generation analysis are described as follows;

\subsubsection{Depth to water table (D)}

The parameter is the measure of depth from the ground surface to the water table. It is therefore a measure of the depth through which a contaminant will travel before reaching the aquifer. Hence, the deeper the water table, the lesser chance for aquifer contamination. Likewise, the shallower the water table, the more vulnerable the aquifer is to contamination. For the purpose of the study, the parameter was obtained by subtracting the water table level from the ground level (with surface level set at $0 \mathrm{~m}$ ). The depth to water table map generated for the study area is presented in Figure 7

\subsubsection{Aquifer Recharge Map (R)}

This parameter represents the amount of water which percolates to the water table by penetrating the ground surface. The recharge water therefore constitutes the contaminants that are transported to the water table. Since the principal source of recharge is precipitation and runoff, the net Recharge parameter was estimated using hydrological precipitation-runoff model from the study area which employs evapotranspiration (E), runoff (Q) and annual precipitation $(\mathrm{P})$ or rainfall from the study area. The aquifer recharge map of the study area is presented in Figure 8

\subsubsection{Aquifer Media Map (A)}

The Aquifer media is considered the saturated permeable geologic zone which contains and transmit water in economic amounts, under ordinary hydraulic gradients. It however, controls the pollutant attenuation processes (Babiker et al., 2005). The larger the grain size (more fractures or openings within the aquifer), the higher the permeability and consequently, the lower the attenuation capacity of the aquifer media. The geological map of the study area was used to further determine the aquifer media index map presented in Figure 9

\subsubsection{Soil Map (S)}

This media represents the uppermost weathered portion of the unsaturated zone which controls the amount of recharge that can infiltrate through the vadose zone, as well as, the aquifer media. It has a significant impact on the amount of recharge that can infiltrate the ground and hence, controls the ability of a contaminant to move vertically into the vadose zone during infiltration process (Chitsazan and Akhtari, 2009). However, it largely depends on the thickness and content of the soil media. The soil map of the study area is presented in Figure 10 


\subsubsection{Topography Map (T)}

This parameter is considered as the slope of the land surface, which dictates whether or not the runoff will stay on the surface (for longer or shorter period) to allow contaminant percolation to the saturated zone (Babiker et al., 2005). With regards to the study, the topography rating map was constructed with the use of elevation map presented in Figure 11 which was derived from the digital elevation model (DEM) using the GIS software. Based on the topography map, flat areas were assigned high rates because they slow down the runoff. This may allow the contaminants to percolate down to reach the groundwater easily, whiles steep areas are assigned low rates due to the increasing rate of the runoff. The topography map of the study area is presented in Figure 12

\subsubsection{Impact of Vadose Zone Map (I)}

The Impact of vadose zone media however, is known to be the unsaturated or the partially saturated zone between the soil layer and groundwater (Ahmet, 2012). Therefore, for the purpose of this research, the aquifer media ratings were used to characterize the impact of vadose zone map which yielded the same map as in Figure 13

\subsubsection{Hydraulic conductivity map (C)}

This refers to the ability of aquifer materials to transmit water, which in turn, controls the rate at which groundwater will flow under a given hydraulic gradient (Aller et al., 1987). Thus, it is the amount of water that flows under an imposed hydraulic gradient. Therefore, the rate of transmitted contaminant along with water, is directly proportional to the flow rate of the groundwater. For the purpose of this study, the hydraulic conductivity map was determined according to the soil conditions and presented in Figure 14

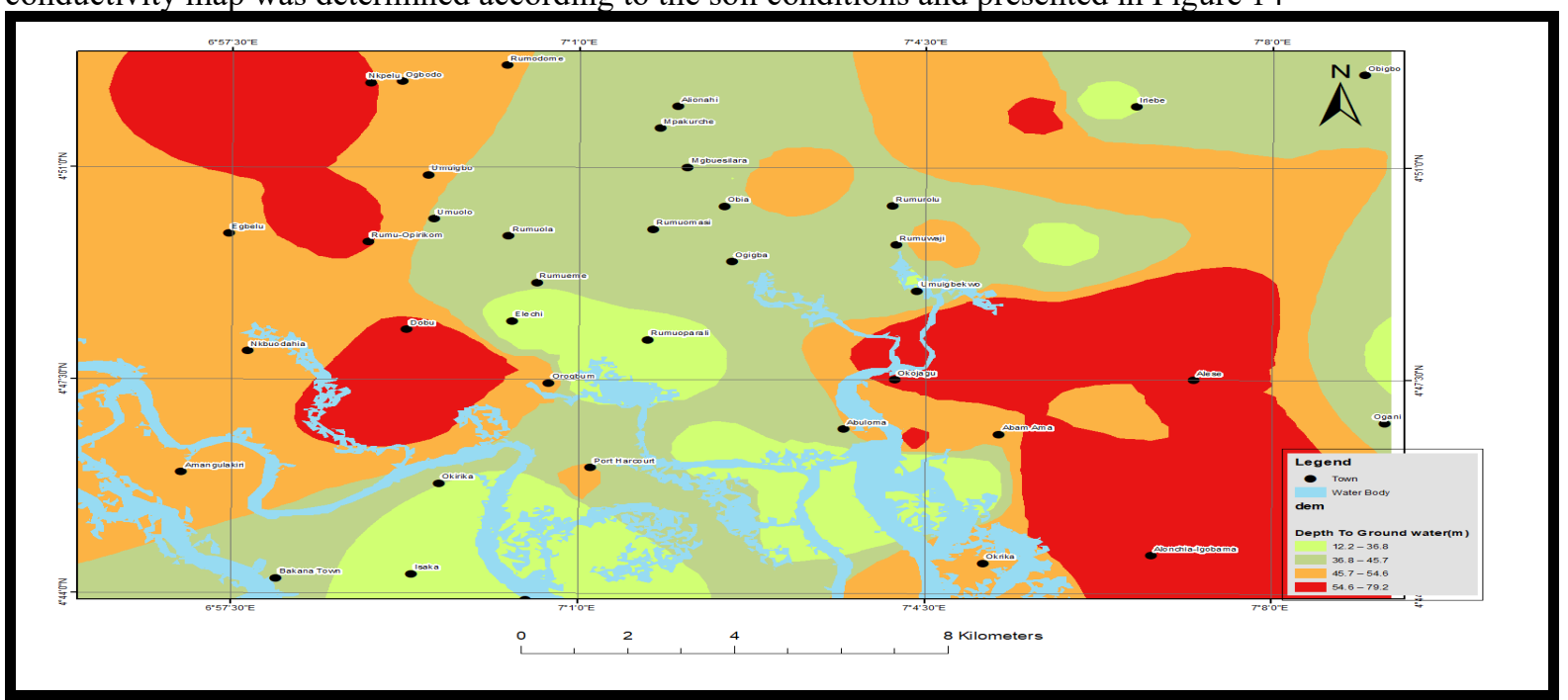

Figure 7: Depth to water table map

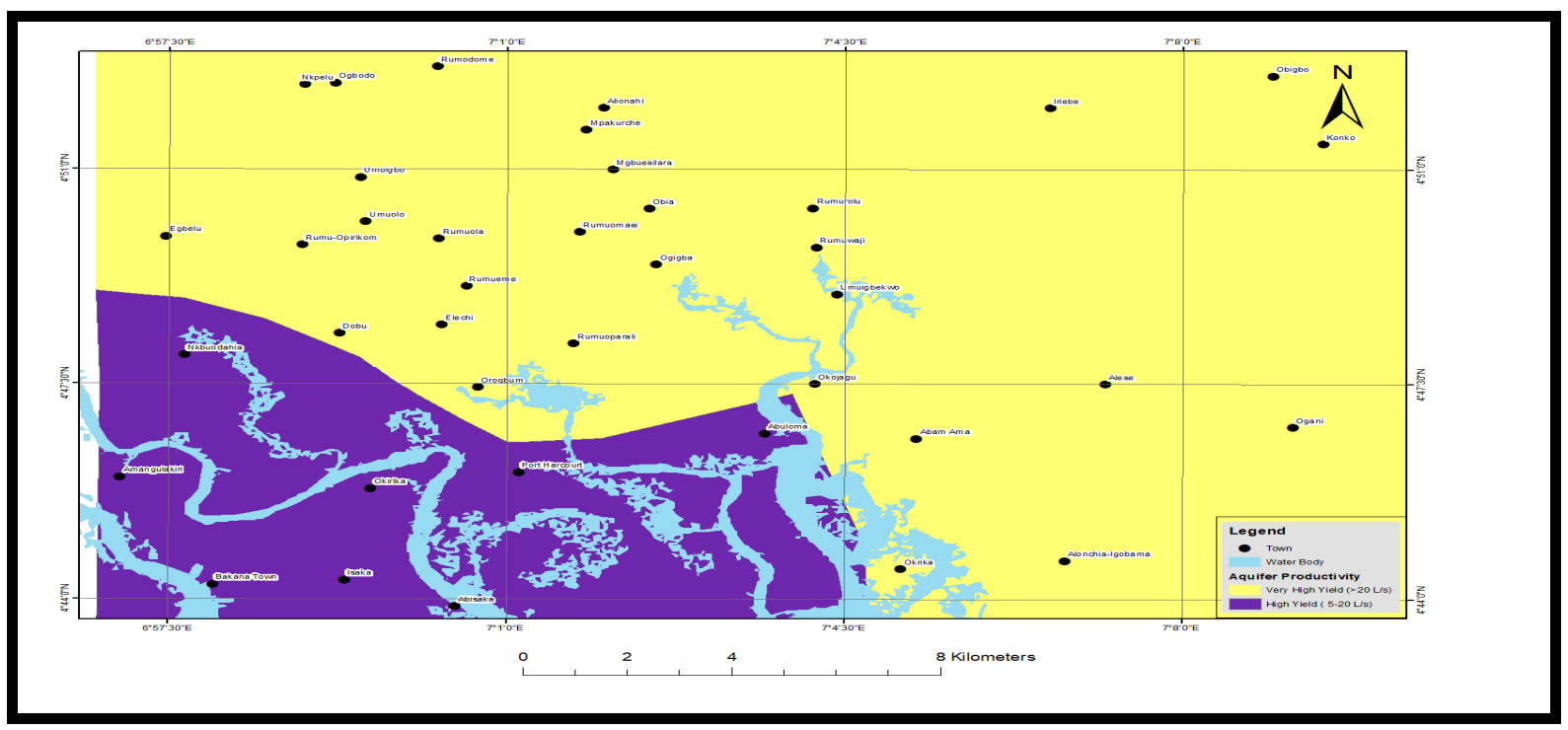

Figure 8: Net aquifer recharge map 


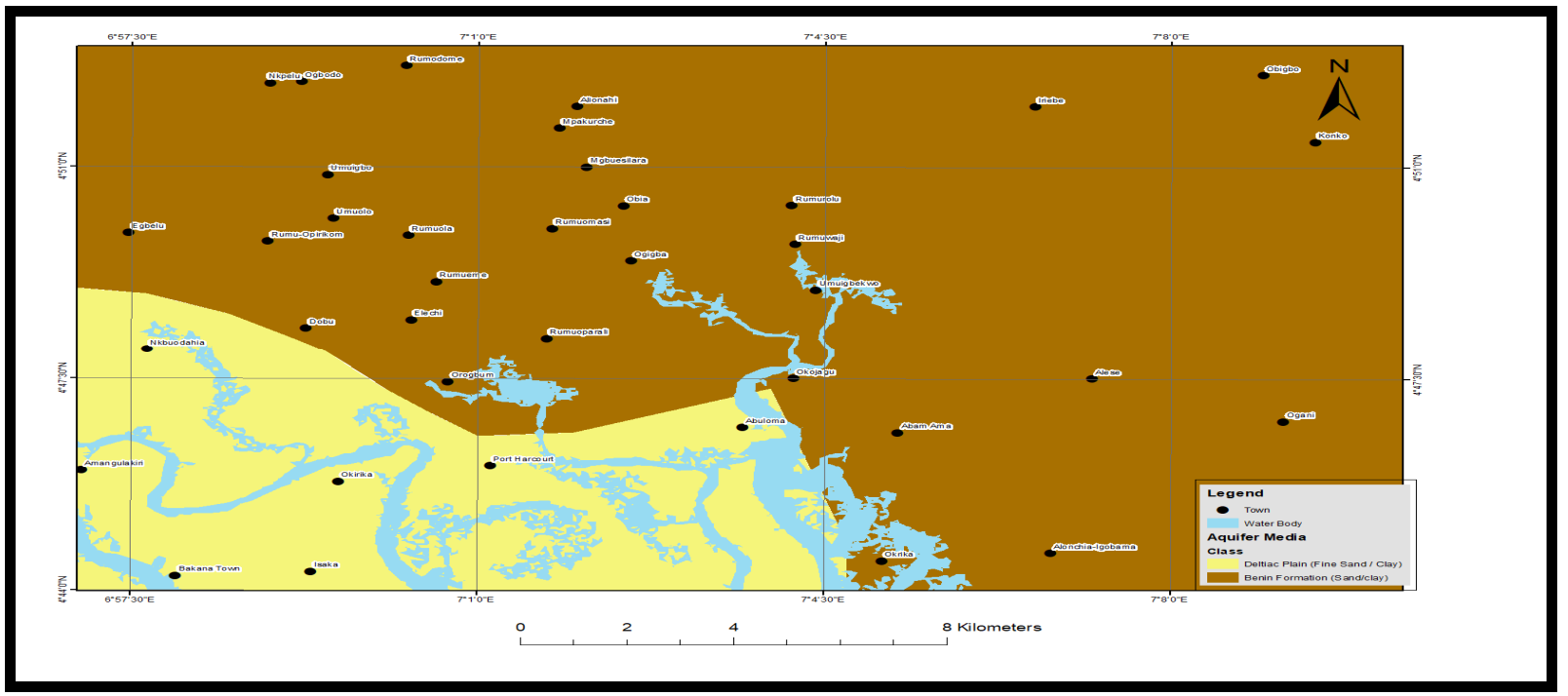

Figure 9: Aquifer media map of study area

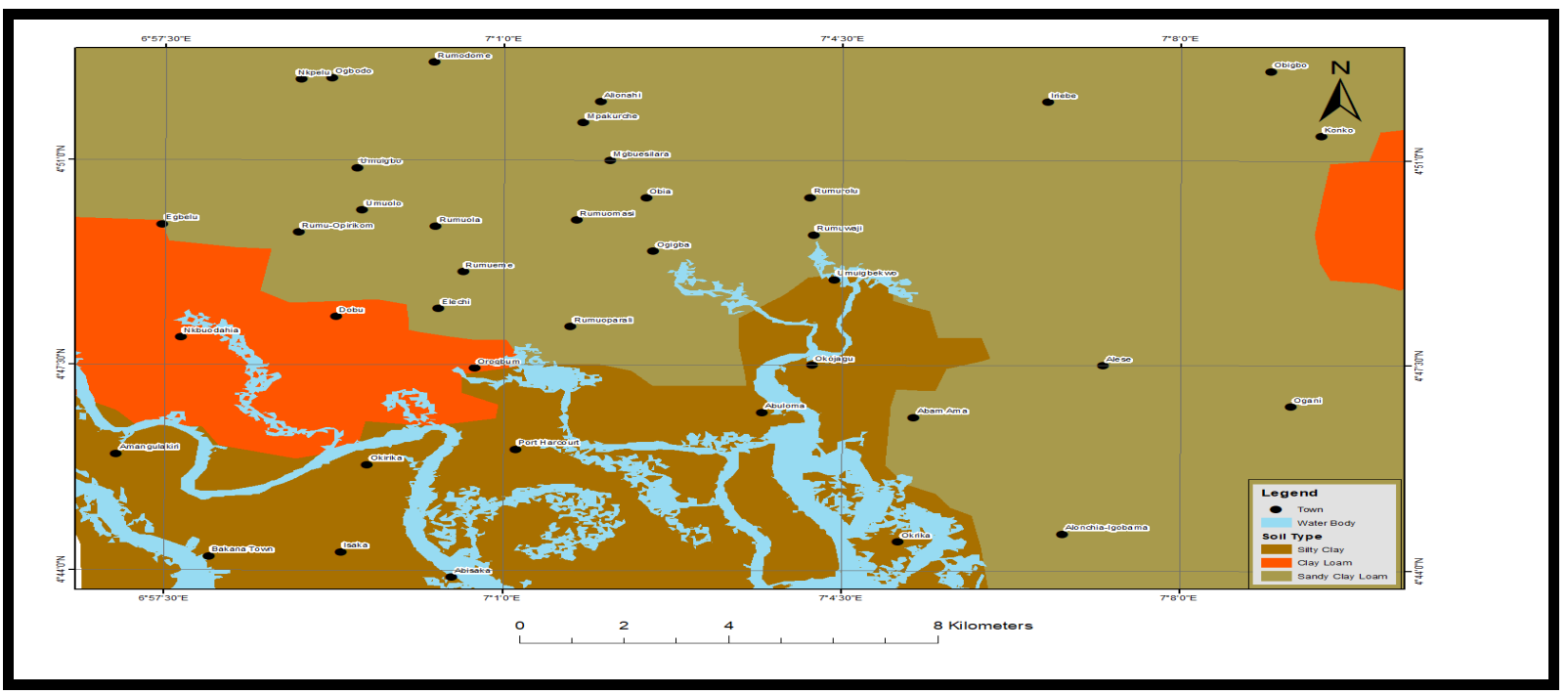

Figure 10: Soil map of study area

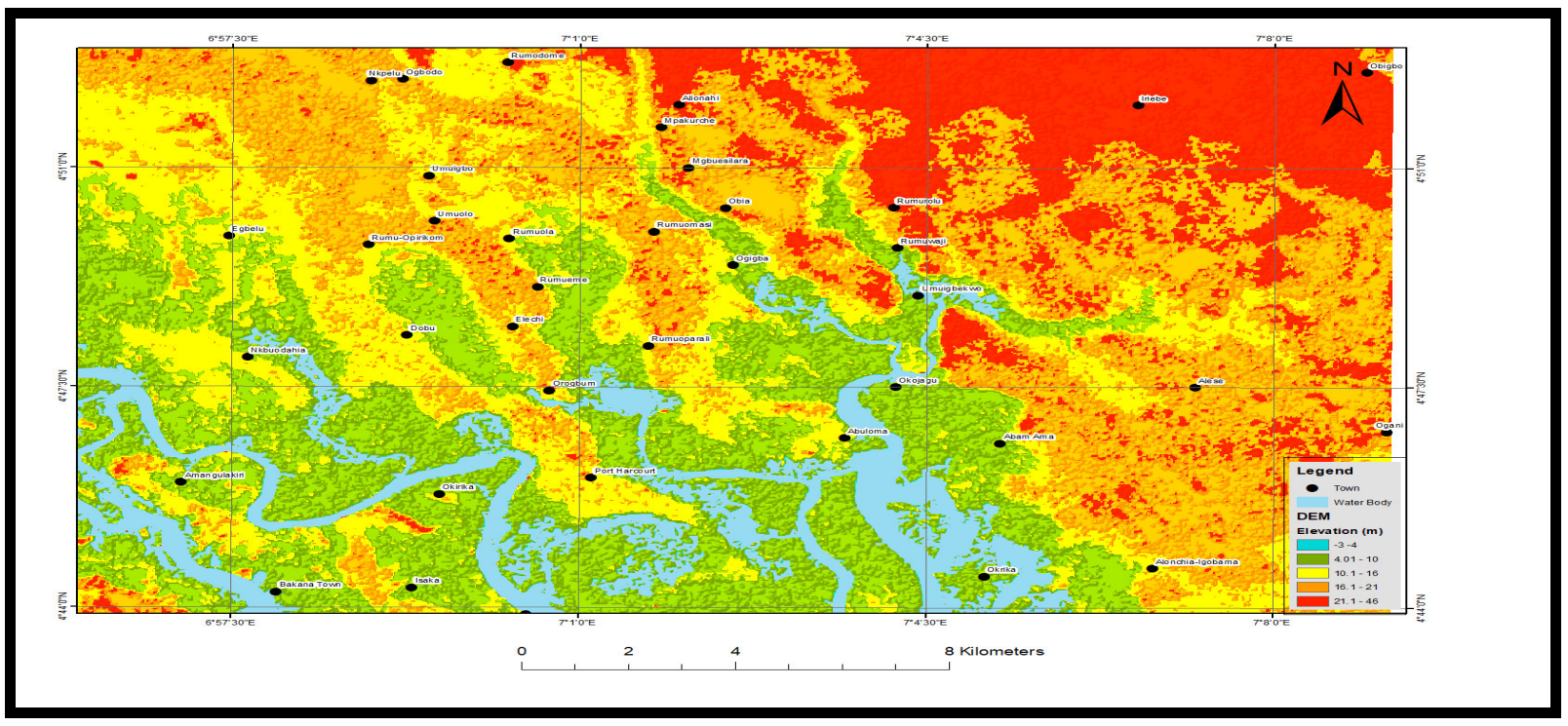

Figure 11: Elevation map of study area 


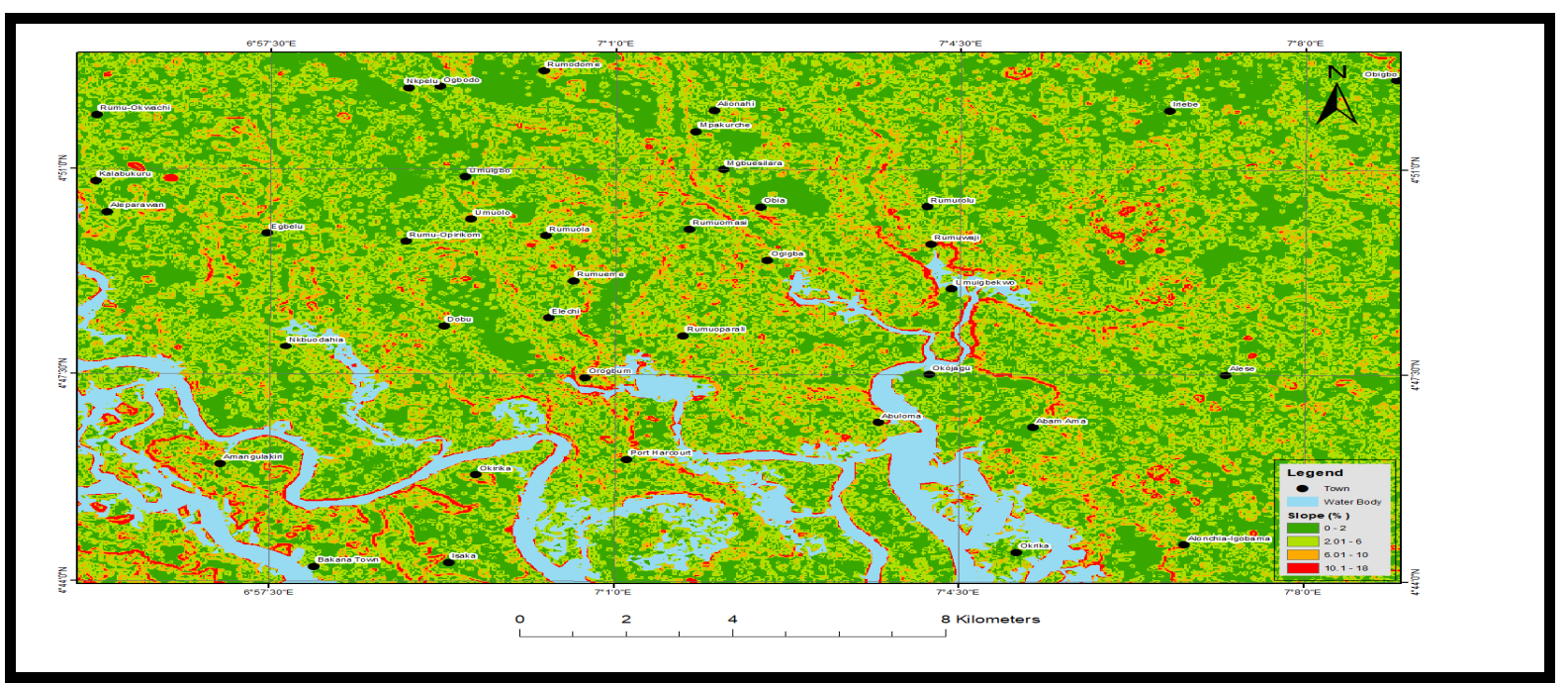

Figure 12: Topography map of study area

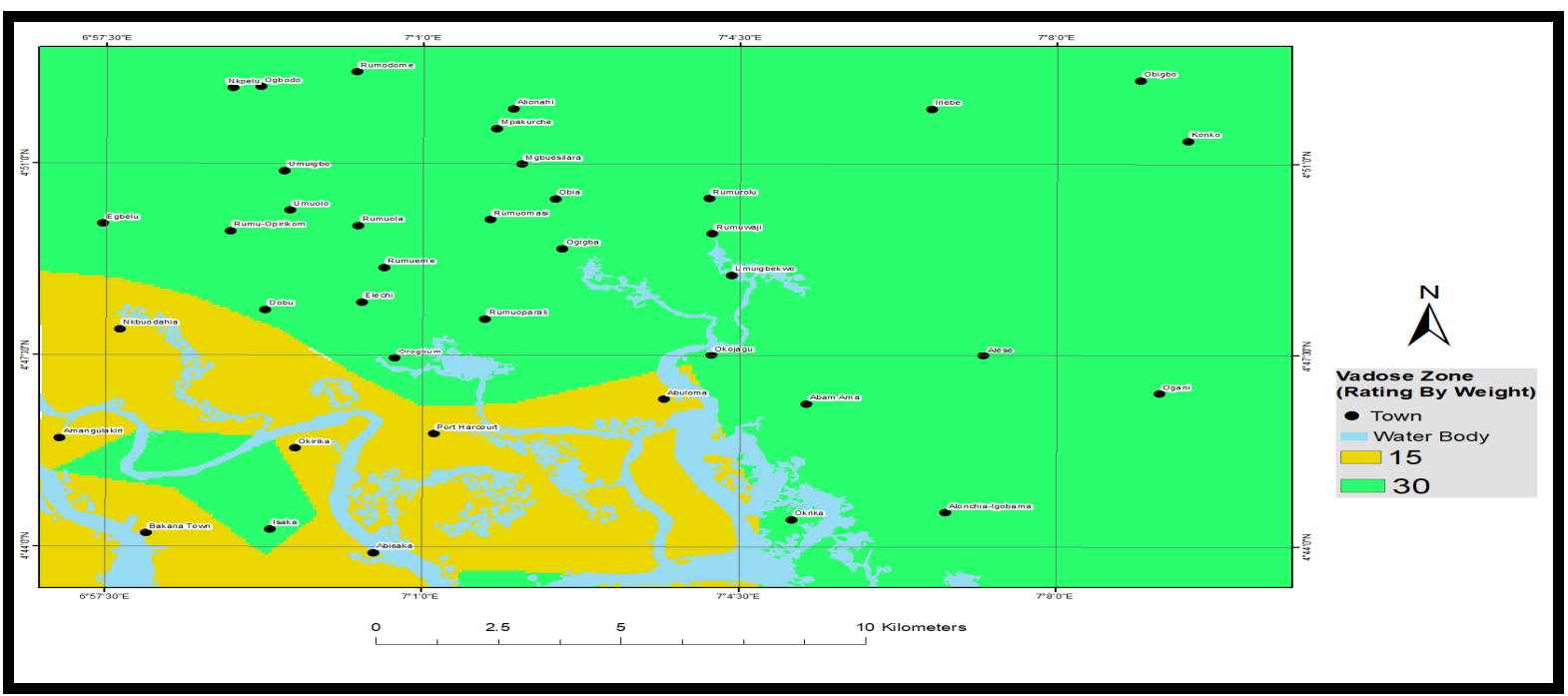

Table 13: Vadose zone map of study area

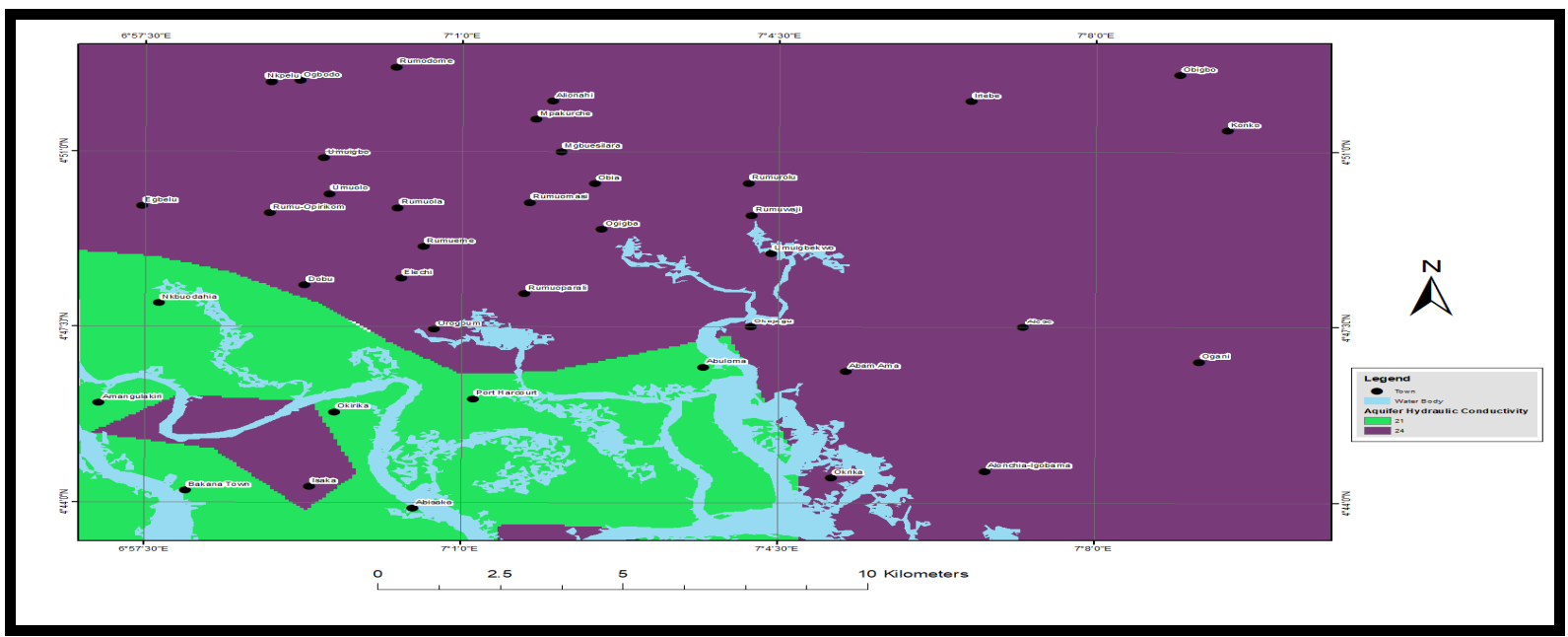

Table 14: Hydraulic Conductivity map of study area

3.4 Generation of DRASTIC Vulnerability Index Map

The weighted overlay of the seven parameters yielded the vulnerability index map. The overlay of all the seven DRASTIC parameters, revealed that, the soil type (S), impact of vadose zone (I), aquifer media (A) and 
hydraulic conductivity (C) greatly influenced the DRASTIC Vulnerability Index Map (VIM), considering their respective weight of 5,4 and 3. Details of the assigned weights and the overall governing equation is presented in Table 5

Table 5; Drastic parameters and the corresponding weight

\begin{tabular}{|c|c|c|}
\hline S/No & Drastic parameters & Weight specification \\
\hline 1 & Depth to water & 3 \\
\hline 2 & Net Aquifer Recharge & 2 \\
\hline 3 & Aquifer Media & 4 \\
\hline 4 & Soil Media & 5 \\
\hline 5 & Topography & 5 \\
\hline 6 & Impact of the vadose zone medial & 4 \\
\hline 7 & Hydraulic conductivity of the aquifer & 5 \\
\hline
\end{tabular}

Based on the result of Table 5; the overall DRASTIC equation that can be employed to calculate the index was formulated as;

DRASTIC Index $=3 \mathrm{Dr}+2 \mathrm{Rr}+4 \mathrm{Ar}+5 \mathrm{Sr}+1 \mathrm{Tr}+5 \mathrm{Ir}+4 \mathrm{Cr}$.

In addition, pairwise weight overlay method was then applied to super-imposed the different maps based on their level of contributory influence. To apply the pairwise weight overlay method, the DRASTIC component maps were first classified in order of priorities; (Soil media, impact of vadose zone media, hydraulic conductivity of aquifer, aquifer media, depth to water, net aquifer recharge and topography. Results of the priorities classification is presented in Figures; 15, 16, 17, 18, 19, 20 and 21. DRASTIC approach allocates specific weight and rate for each parameter in order to calculate aquifer vulnerability index. A final DRASTIC map was thereafter generated using the pairwise overlay method as presented in Figure 22

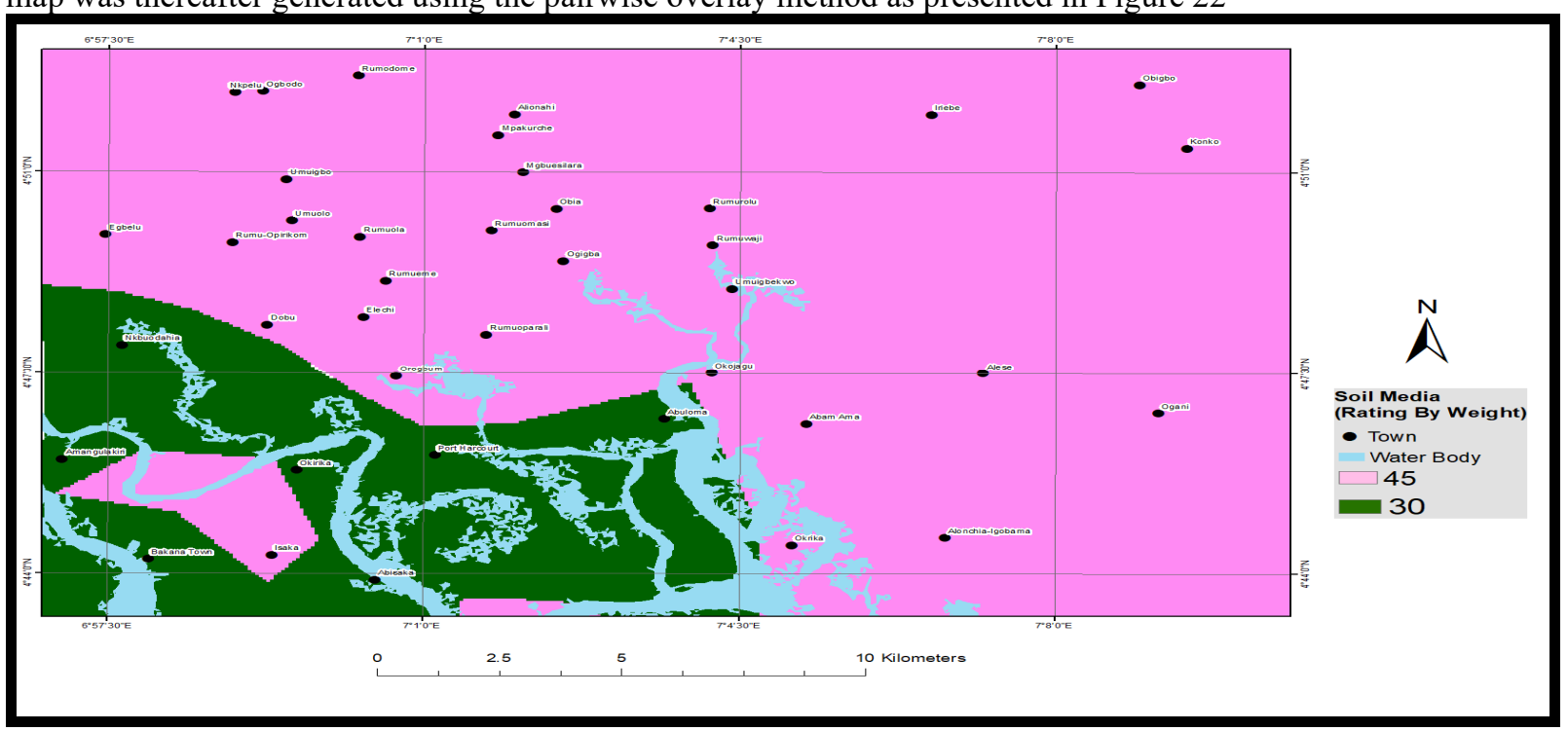

Figure 15: Classified soil media map (S) 


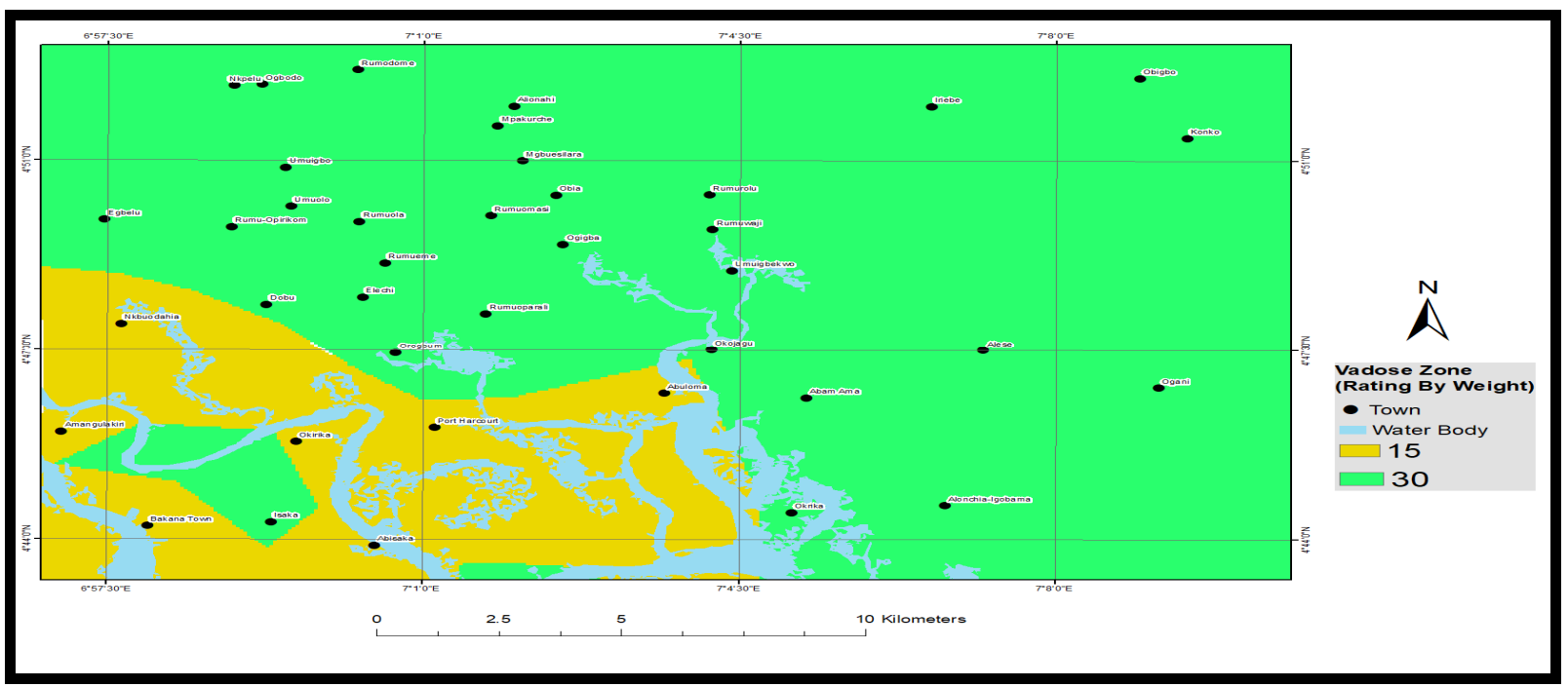

Figure 16: Classified impact of vadose zone map (I)

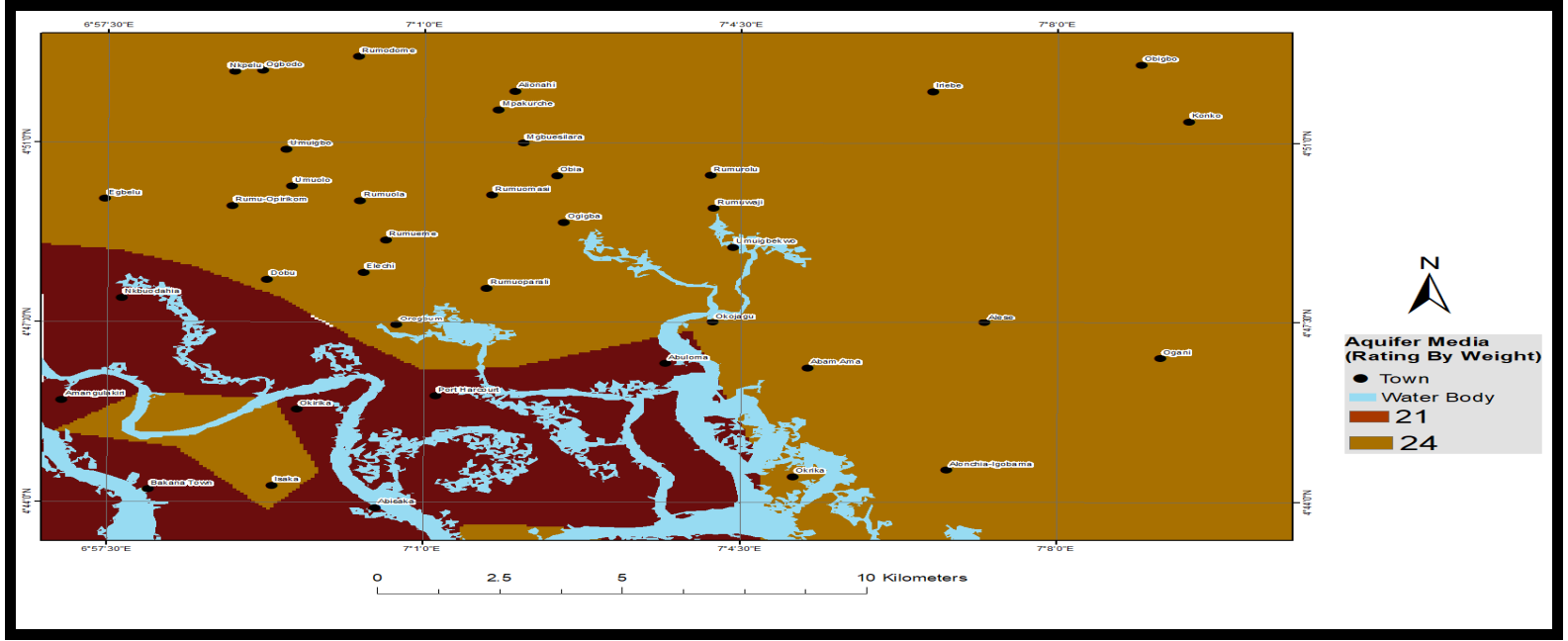

Figure 17: Classified aquifer media map (A)

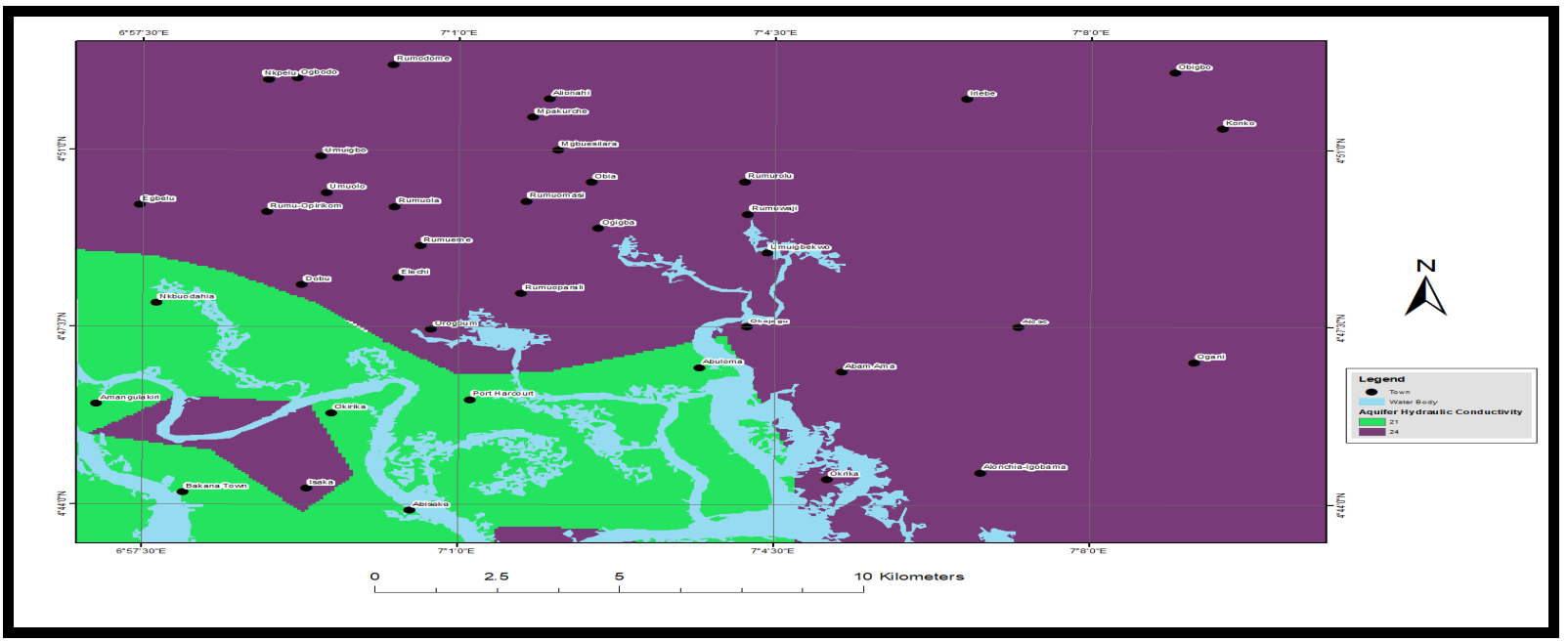

Figure 18: Classified aquifer hydraulic conductivity (C) 


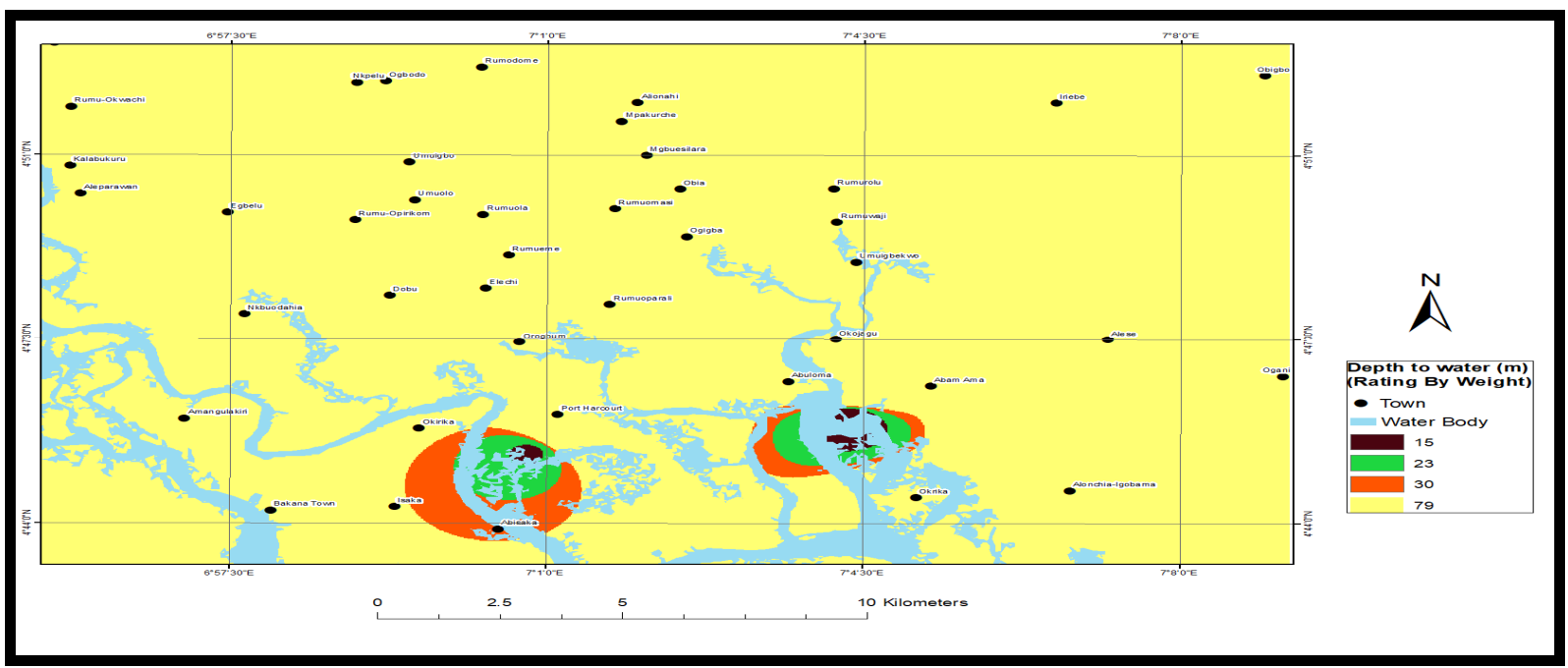

Figure 19: Classified depth to water (D)

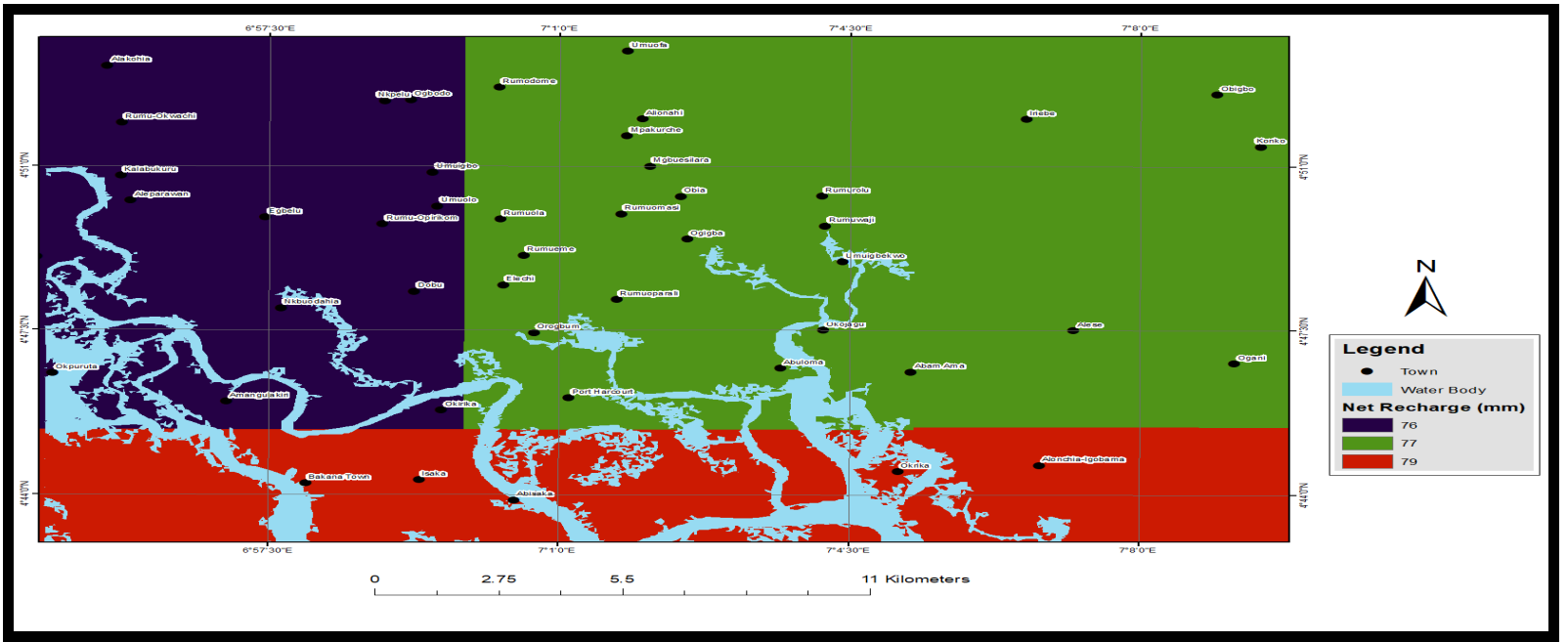

Figure 20: Classified aquifer net recharge (R)

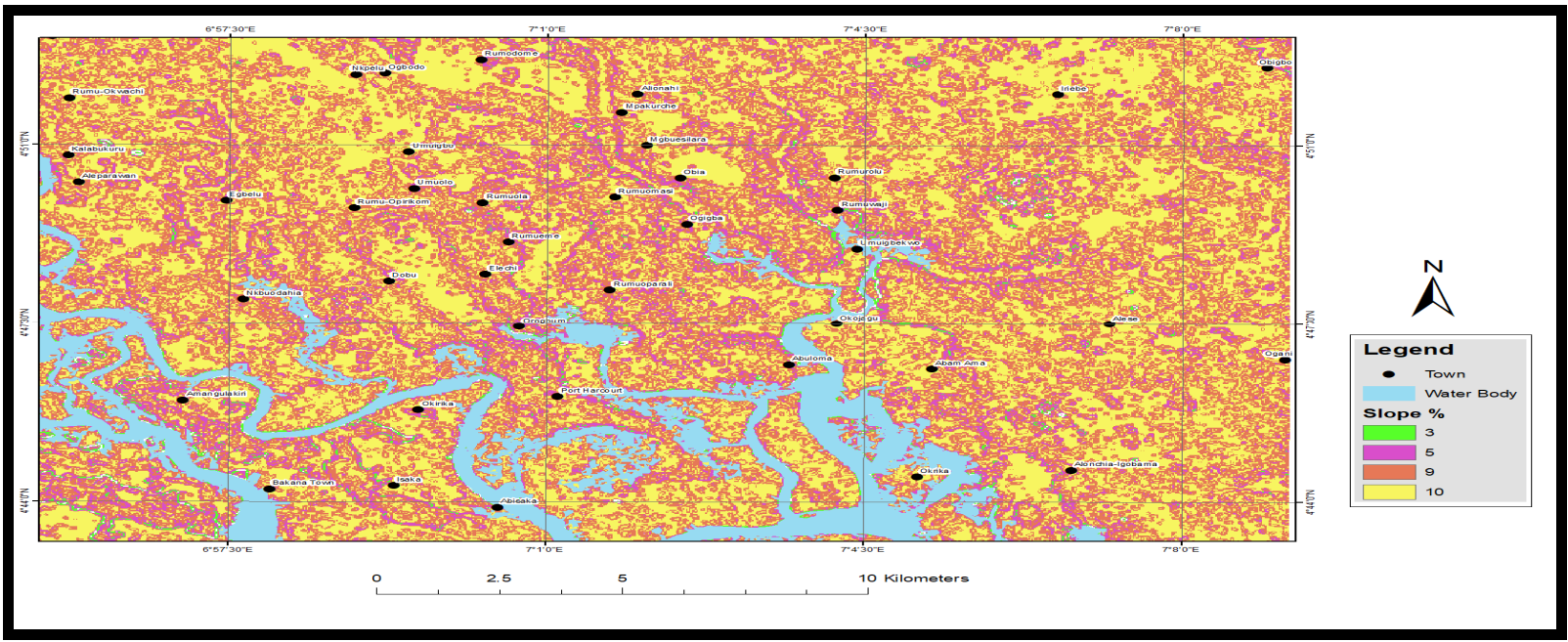

Figure 21: Classified topography map (D) 


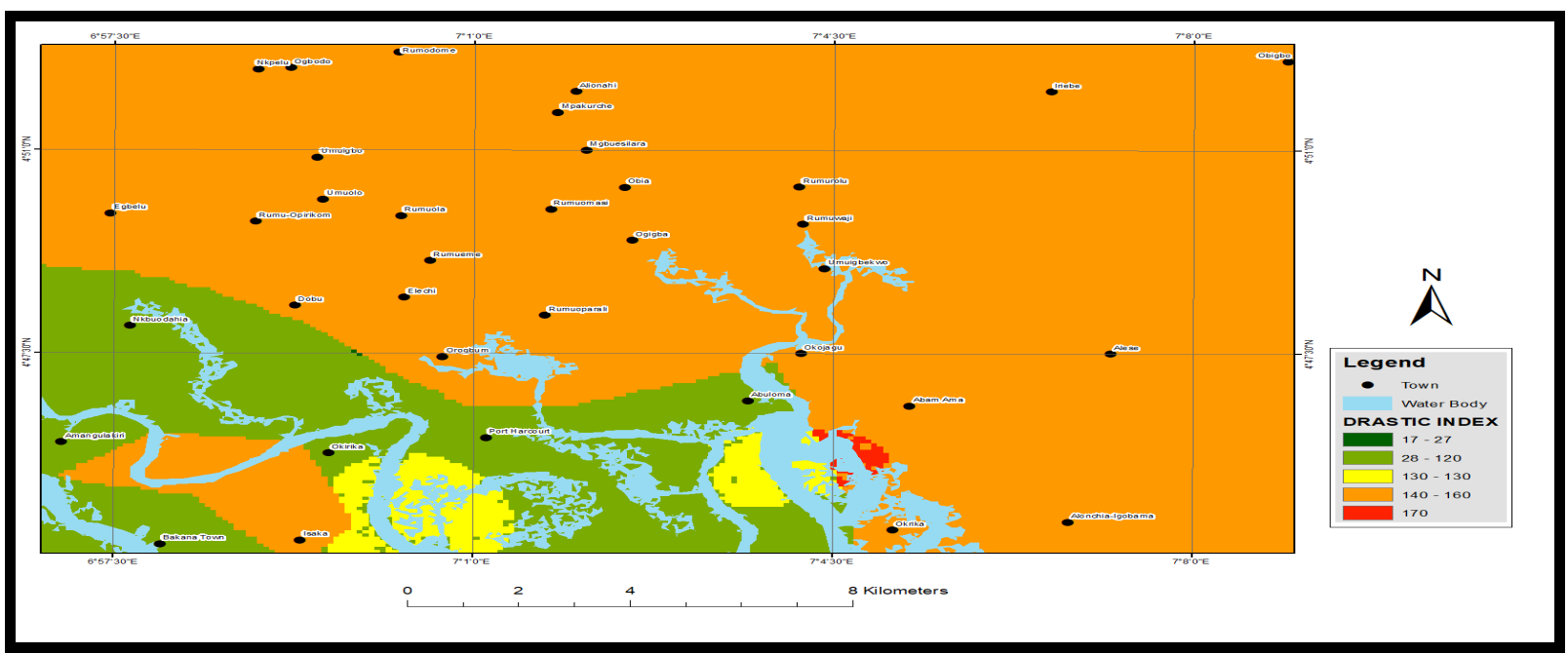

Figure 22: Final DRASTIC map of the study area

Using the result of Figure 22, an explanatory table showing the ranges and colour codes for DRASTIC indices was generated and presented in Table 6

Table 6: Colour codes for DRASTIC Indices

\begin{tabular}{|c|c|c|c|}
\hline S/No & Calculated Index Values & Colour Codes & $\begin{array}{c}\text { Remark } \\
\text { (Vulnerability Rate) }\end{array}$ \\
\hline 1 & $17-27$ & Dark Green & Very Low \\
\hline 2 & $28-120$ & Light Green & Moderate \\
\hline 3 & 130 & Yellow & High \\
\hline 4 & $140-160$ & Light Brown & Very High \\
\hline 5 & 170 and Above & Red & \\
\hline
\end{tabular}

Based on the final DRASTIC map, it was observed that most of the locations from where water samples were collected fell within the light brown colouration with computed DRASTIC index of between (140-160) indicating high rate of vulnerability of the aquifer to contamination. Some of the areas that fell within this region include; Nkpeluogbodo, Rumodome, Umuigbo, Egbelu, Umuolo, Rumuopirikom, Rumuola, Rumueme, Alionahi, Mpakurche, Mgbuesilara, Obia, Rumuomasi, Ogigba, Rumurolu, Rumuwaji, Dohi, Elechi, Rumuoparali, Umuigbekwo, Okojagu.

\section{Conclusion}

The study was conducted to evaluate the quality of the groundwater around the Niger Delta Basin Development Authority and assess the aquifer characteristics and its vulnerability to contamination. Results of the study have shown that a high degree of variability exist in the quality of groundwater collected from different locations within the study area. In addition, the lithological mapping of the study area has revealed the sandy nature of the soil which makes it highly vulnerable to contamination. Based on the final DRASTIC map, it was observed that most of the locations from where water samples were collected fell within the light brown colouration with computed DRASTIC index of between (140-160) indicating high rate of vulnerability of the aquifer to contamination.

\section{References}

1. Ahmet, B. H., (2012). Groundwater vulnerability assessment with drastic method: A case-study on Kirikkale plain, Turkey. MSc Thesis; Department of Civil Engineering, the Graduate School of Natural and Applied Sciences of Middle East Technical University, 1-70.

2. Aller, L; Bennet, T; Leher, J.H; Petty, R.J and Hackett, G (1987); DRASTIC: A standardized system for evaluating ground water pollution potential using hydrogeological settings, Environmental Protection Agency, EPA 600/2-87-035.

3. APHA (2005), Standard Methods for the Examination of Water and Wastewater, 18th edition, American Public Health Association Washington D C

4. Baalousha, H. (2010): Assessment of a groundwater quality monitoring network using vulnerability mapping and Geostatistics; A case study from Heretaunga Plains, New Zealand. Agriculture and Water Management Journal, vol. 97, 240-246.

5. Babiker I.S, Mohamed A.A. Mohamed, Tetsuya Hiyama, Kikuo Kato (2005). A GIS-based DRASTIC model for assessing aquifer vulnerability in Kakamigahara Heights, Gifu Prefecture, central Japan. Science 
of the Total Environment, vol. 345, 127- 140.

6. Chitsazan, M. and Akhtari, Y., (2009). A GIS based DRASTIC Model for Assessing Aquifer Vulnerability in Kherran Plain, Khuzestan, Iran, Water Resources Management, vol.23, 1137-1155.

7. Debels, P., Figueroa, R., Urrutia, R., Barra, R., and Niell, X., (2005), Evaluation of water quality in the Chillan River (Central Chile) using physicochemical parameters and a modified water quality index, Environmental Monitoring and Assessment, 110, 301-322.

8. Gogu, R.C, Dassargues, A (2000) Current trends and future challenges in ground-water vulnerability assessment using overlay and index methods. Environ Geol. Vol. 39(6), 549-559

9. Houan H, Wang J, Teng Y (2012) Assessment and validation of groundwater vulnerability to nitrate based on a modified DRASTIC model: a case study in Jilin city of northeast China. Sci Total Environ 440:14-23

10. Kazakis N and Voudouris K (2011) Comparison of three applied methods of groundwater vulnerability mapping: a case study from the Florina basin, Northern Greece. In: Advances in the research of aquatic environment, vol. 2. Springer, Berlin, Heidelberg, 359-367

11. Ne'mat Sadeq, A.R.Q (2006): Assessment of Groundwater Vulnerability to Contamination in the West Bank, Palestine; Unpublished Master's thesis submitted to An-Najah National University Faculty of Graduate Studies

12. Nwankwoala, H.O.; Eludoyin, O.S. and Obafemi, A.A. (2012): "Groundwater Quality Assessment and Monitoring Using Geographic Information Systems (GIS) In Port Harcourt, Nigeria." Ethiopian Journal of Environmental Studies and Management (EJEM) Vol. 5(4), 583-5967.

13. Shweta, T; Bhavtosh, S; Prashant, S and Rajendra, D (2013); Water Quality Assessment in terms of Water Quality Index, American Journal of Water Resources, Vol. 1(3), 34-38

14. Sinanh, M and Razack, M (2009); An extension to the DRASTIC model to assess groundwater vulnerability to pollution: application to the Haouz aquifer of Marrakech (Morocco), Journal of Environmental Geology, vol. 57, 349-363.

15. World Health Organization (2003): "Manual of Basic Technique for a Health laboratory" World Health Organization, $2^{\text {nd }}$ Edition, Geneva. 